\title{
Identifying Significant Cognitive Factors for Practicing and Learning Meteorology
}

\author{
PEGGY M. MCNEAL \\ Towson University, Towson, Maryland \\ HEATHER L. PETCOVIC \\ Western Michigan University, Kalamazoo, Michigan \\ NICOLE D. LADUE \\ Northern Illinois University, DeKalb, Illinois \\ TODD D. ELLIS \\ Western Michigan University, Kalamazoo, Michigan
}

(Manuscript received 1 November 2018; review completed 17 January 2019)

\begin{abstract}
Understanding which cognitive factors facilitate meteorology skills is important for meteorology training and education. This study investigated aspects of cognition important to successful completion of meteorology tasks typically provided to student meteorologists. With a sample of 81 participants - spanning the range of experience from undergraduate students to professional meteorologists-we administered two spatial thinking tests, a visuospatial working memory test, a concept inventory, and an experience questionnaire. We compared the resulting scores to performance on a series of novice-level meteorology tasks. An analysis of the data suggests that meteorology knowledge along with disembedding skill (the ability to observe and recognize patterns among nonessential information) positively predicts performance on the meteorological tasks. The relationship among meteorology knowledge, disembedding skill, and performance on the meteorology tasks indicates that disembedding is an important predictor of success at both low and high levels of meteorology knowledge. Thus, our results suggest that individuals with heightened ability to identify patterns embedded in distracting background displays may be at an advantage for completing meteorology tasks of the type that we provided.
\end{abstract}

\section{Introduction}

Investigations into the effect of specific cognitive factors on performance have been conducted within a wide range of tasks and domains, including geologic bedrock mapping (Hambrick et al. 2012), air traffic controlling (Ackerman et al. 1995), and piano sightreading (Meinz and Hambrick 2010). These studies provide insight into what determines individual differences in skill acquisition, compare expert to novice performance, and reveal the interplay of multiple cognitive factors during complex task processing.

In perhaps the most relatable example to meteorology, multiple studies have contributed significantly to understanding geology from the perspective of cognitive science (Liben and Titus 2012; Shipley et al. 2013). This has included identifying and describing specific factors that contribute to geologic reasoning and task execution (e.g., Kali and Orion 1996; Liben et al. 2011; Ormand et al. 2014) and the effect of these factors on novice through expert performance (Hambrick et al. 2012). A result of this research is 
that several spatial thinking skills are instrumental to completing geologic tasks (Newcombe and Shipley 2015). One example is the ability to imagine the interior cross section of an object from exterior cues-a skill critical for geologists who work with roadcuts, cross sections, thin sections, and other "Earth slices" to interpret geologic processes (Titus and Horsman 2009). A second example is the ability to rotate objects mentally, which is a skill essential for understanding the motion of tectonic plates and crystal symmetry.

Overall, spatial thinking is important to learning in science, technology, engineering, and math (STEM) fields (Wai et al. 2009). Research has established that many spatial thinking skills are malleable (Uttal et al. 2013) and improve with training. This has spurred a large body of research in STEM education that particularly informs the education and training of geologists (Atit et al. 2016). Focused efforts to develop instructional materials include a research-validated spatial skills curriculum for geology majors that intentionally and purposefully supports student understanding of spatially challenging concepts and skills (Ormand et al. 2017).

Like geologists, operational meteorologists regularly perform cognitively complicated tasks that involve analyzing data from satellite images, radar, and remote sensors, while digesting output from numerical model guidance. Human performance studies in meteorology have exposed revelatory and practical insights about operational meteorology, such as decision making (Joslyn and Jones 2008; Wilson et al. 2016), mental health (Bolton et al. 2018), color salience and interpretation of displays (Bryant et al. 2014), factors of workstation design (Hoffman 1991), and forecaster use of mental models (Trafton et al. 2000). However, the way that specific cognitive factors affect performance of meteorological tasks is an under-investigated area, yet one that may yield insight into how to best train and educate operational meteorologists. Thus, recognizing the research foundation established by geoscience education researchers, we were compelled to work at the intersection of cognitive science, meteorology, and meteorology education research, where we could investigate meteorology practice and learning via a cognitive science lens. Identifying significant cognitive factors for practicing and learning meteorology is an important part of understanding human performance in this domain, and one that may contribute significantly to the education and training of operational meteorologists.

We used Cattell-Horn-Carroll (CHC) theory to frame our investigation because it allowed us to differentiate between malleable aspects of cognition that are improvable with training, along with stable components of intelligence that exhibit a range of human variability. According to McGrew (2009), CHC theory is a working taxonomy of intelligence factors used as a theoretical framework from which to test hypotheses regarding various aspects of human cognition, and it is widely regarded as the most influential theory in the study of human intelligence. $\mathrm{CHC}$ describes sixteen broad abilities contributing to general intelligence that are further divided into narrow abilities. Of these, we were interested in investigating five narrow abilities: working memory (a component of short-term memory), spatial relations and flexibility of closure (components of visual processing), and expertise and domain knowledge (components of general, domain-specific knowledge). We turn now to a more detailed look at the individual factors we investigated, along with our rationale for inclusion.

$\mathrm{CHC}$ theory defines visual processing as "the ability to generate, store, retrieve, and transform visual images and sensations" (McGrew 2009, p. 5). To investigate visual processing factors, we assessed mental rotationpart of spatial relations in CHC theory, but also broadly associated with spatial visualization (McGee 1979) and disembedding, or what $\mathrm{CHC}$ theory refers to as flexibility of closure.

Mental rotation involves rotating mental representations of two-dimensional (2-D) and threedimensional (3-D) objects (Manduca and Kastens 2012). We chose to investigate mental rotation because of its role in spatial visualization that presumably is important to meteorologists who must understand atmospheric dynamics and the overturning motions of 3-D, largely invisible fluids. Kastens and Ishikawa (2006) additionally proposed that mental rotation skill is related to map usage; thus, it is a potentially important factor for meteorologists, who work with an abundance of map-referenced data.

Disembedding consists of observing and recognizing patterns, and isolating important aspects from distracting, nonessential ones (Manduca and Kastens 2012). Our choice to investigate disembedding resulted from a prior investigation that sought to

\footnotetext{
${ }^{1}$ McGrew (2009) used the word "abilities" to refer to discrete factors that together describe the structure of human intelligence. In an attempt to stay true to language used in other sources and avoid unintended characterizations of individuals' capability or potential to perform, we will continue with use of the word "factors" to refer to discrete aspects of human intelligence.
} 
identify which spatial skills meteorologists report using in their work (McNeal et al. 2018). The results suggested disembedding as worthy of investigation; $72 \%$ of the meteorologists in the sample $(\mathrm{N}=93)$ reported using disembedding while interacting with nine meteorological charts and images.

Working memory - the ability to maintain taskrelevant information in a highly active state-is an inherited aspect of intelligence (Polderman et al. 2006; Kremen et al. 2007), and considered steady throughout one's life (excepting age-related decline). CHC theory categorizes working memory as part of overall shortterm memory; however, working memory involves intervening processing and, therefore, specifically describes the ability to process and hold information simultaneously (Wiley et al. 2014). We investigated working memory capacity owing to its important role in STEM learning (Jaeger et al. 2017) and because of it being an influential cognitive component in forecasting (Joslyn and Jones 2008).

Domain knowledge results from an accumulation of school and lifetime experiences that can be measured through concept inventories and tests of the factual knowledge required for understanding a field. Not only is possessing sufficient domain knowledge fundamental to expertise (Wiley 1998), but the way that this knowledge is organized enhances its accessibility, functionality, and efficiency (Bédard and Chi 1992).

A related, yet distinct, component of domain knowledge is expertise. Expertise studies have a history tracing back to de Groot's (1965) work with expert chess players. Chase and Simon (1973) continued this line of research, as well as Charness (1991), who suggested that the advantage held by master chess players results from an extensive mental library of chess positions and the ability to recognize patterns. Specifically, Chase and Simon (1973) found that expertise in chess derives from the ability to encode individual chess positions into perceptual chunks representing familiar configurations. Hypothesizing that meteorologists use similar processes when recognizing weather patterns prompted us to investigate knowledge and expertise as well.

We designed our research within the framework of $\mathrm{CHC}$ theory to investigate the cognitive factors considered in our study and answer our research question: What effects do working memory, domain knowledge, mental rotation, disembedding, and expertise have on performance on a series of meteorology tasks?

\section{Data and methods}

Our research used a cross-sectional design that included professional and student meteorologists. We collected data from November 2016 through September 2017 at three universities, a National Weather Service (NWS) Forecasting Office, a United States Navy Fleet Weather Center, and a professional conference. We administered an experience questionnaire - along with tests of mental rotation, disembedding, visuospatial working memory, and meteorology knowledgefollowed by a series of meteorology tasks. We conducted a quantitative analysis of the data to seek correlations and compare means before performing a regression analysis to investigate the effects of the targeted cognitive factors on meteorology task performance. We used IBM's Statistical Package for the Social Sciences (SPSS) version 24 for data analysis (www.ibm.com/ analytics/spss-statistics-software).

We sought a wide range of expertise, thus we targeted undergraduate and graduate meteorology students, university meteorology faculty, and military and civilian operational forecasters. To recruit participants, we used professional networks to identify gatekeepers at host institutions. The gatekeeper distributed an email to potential participants with requisite skills for completing the forecasting task (specifically skills learned in upperlevel undergraduate meteorology courses, typically at the junior or senior level). They directed individuals interested in participating in the research to contact the first author. The first author provided more information to potential participants and arranged a meeting. Upon meeting, individuals were briefed on the research and signed an informed consent. Table 1 gives detailed information about our data sources. Our sample included 81 participants who ranged in age from 19 to $64 \mathrm{yr}$ with an average age of $27.3 \mathrm{yr}\left(\mathrm{SD}_{\text {age }}=1.2\right.$, where $\mathrm{SD}=$ standard deviation). Our sample was $63 \%$ male and $27 \%$ female, which, owing to the inclusion of students in our sample, exceeds current estimates of the participation of women in atmospheric sciences [i.e., MacPhee and Canetto (2015) reported that $17 \%$ of the American Meteorological Society (AMS) membership, excluding students, was female in 2005]. Information about the experience level of our participants is included in Table 2.

Data collection occurred with participants individually, or in groups of up to five participants with each participant working individually. Participants completed established, valid, and reliable psychometric 
Table 1. Sources of participants and data collection.

\begin{tabular}{|l|l|l|}
\hline \multicolumn{1}{|c|}{ Institution Type } & \multicolumn{1}{|c|}{ Participants } & \multicolumn{1}{c|}{ Dates of Data Collection } \\
\hline University 1 & $\begin{array}{l}13 \text { undergraduate students } \\
6 \text { graduate students } \\
3 \text { faculty }\end{array}$ & November 2016 \& September 2017 \\
\hline University 2 & $\begin{array}{l}9 \text { undergraduate students } \\
4 \text { graduate students } \\
1 \text { faculty }\end{array}$ & April 2017 \\
\hline University 3 & $\begin{array}{l}19 \text { undergraduate students } \\
8 \text { graduate students } \\
2 \text { faculty }\end{array}$ & April \& September 2017 \\
\hline NWS Forecast Office & $\begin{array}{l}6 \text { operational forecasters } \\
1 \text { student intern }\end{array}$ & July 2017 \\
\hline U.S. Navy Fleet Weather Center & $\begin{array}{l}3 \text { U.S. Navy aerographer's mates } \\
2 \text { civilian forecasters }\end{array}$ & July-August 2017 \\
\hline Conference Attendees & $\begin{array}{l}3 \text { faculty } \\
1 \text { operational forecaster }\end{array}$ & July 2017 \\
\hline
\end{tabular}

tests including the Educational Testing Service (ETS) Hidden Figures Test (Ekstrom et al. 1976), the Vandenberg and Kuse Test of Mental Rotation (Vandenberg and Kuse 1978), and a Matrix Span Test of Visuospatial Working Memory (adopted from Hambrick and Oswald 2005). Participants also completed the Fundamentals in Meteorology Inventory, version 1.5 (FMI, Davenport et al. 2015), a domain and experience questionnaire (DEQ, adopted from Baker et al. 2012 and Petcovic et al. 2016), and a series of meteorology tasks developed for the study. Each measure is described below; participants completed the tests and tasks in the order they are described. On occasions when testing was conducted in groups, the working memory test, which was administered on a laptop, was administered individually while others worked ahead, in turn. Participants were compensated with stipends of only 20 or 50 dollars because of restrictions on gifts that can be accepted by federal employees. Data collection took $1.5-2 \mathrm{~h}$ per individual.

\section{a. ETS Hidden Figures Test}

The ETS Hidden Figures Test measures ability with disembedding/flexibility of closure. It is a timed paper and pencil test that requires subjects to search in a perceptual field containing irrelevant or distracting material in order to find one or more given configurations (Ekstrom et al. 1976). The test asks subjects to decide which of five geometrical figures is embedded in a complex pattern. It consists of two similar sections. Each section contains 16 questions and participants have $12 \mathrm{~min}$ to complete each section. We administered one section of the test to reduce overall test time and diminish test fatigue in participants. We followed scoring procedures described by Danili and Reid (2004) - one point for a correct simple shape embedded in each complex pattern.

\section{b. Vandenberg and Kuse Mental Rotation Test}

We selected the Vandenberg and Kuse Mental Rotation Test because it assesses the ability to transform visual images, a key component of visual processing. It is a timed paper and pencil test that consists of symmetric and asymmetric figures of 3-D objects, drawn in a 2-D isometric format, rotated around a horizontal axis. Each item presents an initial figure followed by four other figures. From the last four figures, subjects select two figures that match the same configuration as the initial figure, only rotated (Vandenberg and Kuse 1978). The test consists of 24 items administered in two sets of 12 with a 3-min time limit for each set. Each item was scored correct only if both correct configurations were selected - to eliminate correct guesses (Vandenberg and Kuse 1978). 
Table 2. Experience information for participants in the study $(\mathrm{N}=78)$.

\begin{tabular}{|l|l|}
\hline Experience & \multicolumn{1}{|c|}{$\%$ Of Sample } \\
\hline Have you completed military weather training? & 8.7 \\
\hline Have you completed (or are enrolled in) college courses? & \\
\hline - Intro to Weather Analysis & 91.4 \\
\hline - Synoptic Meteorology & 67.9 \\
\hline - Dynamic Meteorology & 82.7 \\
\hline - Mesoscale Meteorology & 55.6 \\
\hline - Physical Meteorology & 64.2 \\
\hline - Climatology & 64.2 \\
\hline - Forecasting & 67.9 \\
\hline - Broadcast Meteorology & 11.1 \\
\hline Have you completed/are you working on? & \\
\hline - Internship in atmospheric science & 58.0 \\
\hline - Original research in atmospheric science & 45.7 \\
\hline What is your education level in atmospheric science/meteorology? & \\
\hline - Pursuing an M.A./M.S. & 18.5 \\
\hline - Completed an M.A./M.S. & 23.5 \\
\hline - Pursuing a Ph.D. & 4.9 \\
\hline - Completed a Ph.D. & 12.3 \\
\hline Have you worked professionally as a meteorologist? & \\
\hline - <5 yr & 8.6 \\
\hline - 5-10 yr & 4.9 \\
\hline - >10 yr & 13.6 \\
\hline
\end{tabular}

\section{c. Matrix Span Test of Visuospatial Working Memory}

Several complex-span tests are used to target different aspects of working memory, including visuospatial, verbal, and arithmetic. We measured working memory capacity with a matrix span working memory test adopted from Hambrick and Oswald (2005) and used in prior studies (e.g., Hambrick et al. 2012). The test specifically targets the visuospatial domain of working memory. We administered the test on a computer tablet and scored using partial-credit load scoring (Conway et al. 2005). The test requires subjects to store information in memory while engaging in an unrelated processing task. Specifically, subjects are presented with 36 items, each with an array of L's, followed by a matrix with one cell filled. Subjects circle "yes" if an upside-down $\mathrm{T}$ is included in the array of L's, and attempt to remember the location of the filled cells.

\section{d. FMI}

To measure domain knowledge, we administered FMI version 1.5 (Davenport et al. 2015), an untimed, meteorology concept inventory. The FMI measures the conceptual understanding of fundamental meteorology concepts presented in most introductory courses. Thirty-five multiple choice questions span seven broad topics covered in meteorology courses: clouds and precipitation, wind, fronts and air masses, temperature, stability, severe weather, and climate. We used the FMI as a measure of basic meteorology knowledge commensurate with that of an undergraduate, upperlevel meteorology major (e.g., juniors and seniors) that aligns with the difficulty level of the meteorology task series (described below). The FMI recently has been updated to version 1.6 and underwent reliability testing. A commonly used internal consistency reliability metric for tests with dichotomous correct/incorrect choices is the Kuder-Richardson 20 metric. This was calculated 
for FMI version 1.6 and determined to be 0.78 , which demonstrates that it is a statistically consistent and reliable measure (Davenport and French 2018).

\section{e. $D E Q$}

To measure expertise and gather additional demographic data, we modified valid and reliable surveys from two prior studies (Baker et al. 2012; Petcovic et al. 2016) to make them applicable to weather forecasters, meteorologists, and atmospheric scientists. We pilot tested the DEQ with a small group of meteorology students and faculty and weighted the scoring to favor operational and professional experience. The DEQ is provided in appendix A.

\section{f. Meteorology task series}

To evaluate participants' ability to solve novicelevel meteorology problems, such as those involved in forecasting scenarios, we developed a meteorology task series based on multiple versions of case study problems typically provided to undergraduate meteorology students. We obtained permission and collected surface and upper-air maps from archived data maintained at the Plymouth State University Weather Center (vortex. plymouth.edu/) for the task series that involves a classic midlatitude cyclone event from 2013. Starting with a plotted surface data map, the instructions ask the participant to mark the low-pressure center and draw in warm and cold fronts. The task continues with upper-air maps representing 850,500 , and $300 \mathrm{hPa}$; the participants are asked to annotate troughs and ridges, and shade areas of cold- and warm-air advection, positive and negative vorticity advection, and divergence and convergence. Finally, given a blank map of the United States, the participant predicts and marks the location of the lowest pressure $12 \mathrm{hr}$ later. An external expert evaluator (i.e., a university geography and meteorology department chair) developed a 10-point rubric for evaluation of each map and completed the scoring. The entire meteorology task series is provided in appendix $\mathrm{B}$ and the scoring rubric is in appendix $\mathrm{C}$, which also includes novice and expert examples of completed maps.

\section{Analysis}

We screened the data for outliers and influential cases. We identified three outliers whose meteorology task scores were $>3.5$ SDs below the mean. Upon inspection of their demographic data, we determined that these individuals did not hold the requisite skills for completing the meteorology task; one was an intern at an NWS forecast office but did not have a meteorology background, another was a climatologist, and the third was a student without adequate meteorology coursework. These outlying scores were excluded, leaving a final sample size of 78. Meteorology task scores from this sample were normally distributed. Appendix D contains histograms and normal QuantileQuantile plots for all variables.

Although we purposefully sought a range of expertise, our recruiting resulted in fewerthan anticipated "expert" meteorologists; $27.1 \%$ had operational experience and $12.3 \%$ held a Ph.D. in meteorology, atmospheric science, or a related field. Additionally, the FMI assesses meteorology knowledge at the undergraduate level, and as a result, many participants did quite well. To resolve skewness and kurtosis evident within the expertise and FMI distributions, we used robust methods (bootstrapping) to meet the assumptions of the statistical tests. Additionally, the November 2016 data collection served as an initial pilot study of all tests except the Matrix Span Test of Visuospatial Working Memory. Therefore, for this measure only, $\mathrm{N}=65$. Descriptive statistics for the tests and tasks are provided in Table 3 and correlations are provided in Table 4.

As an extra measure of validity, we performed independent sample $t$ tests to confirm that our data aligned with expected patterns that are documented in the literature. These tests confirm a gender difference with the test of mental rotation (see Newcombe and Stieff 2012). Males had higher mental rotation scores (mean = $\mathrm{M}=10.39, \mathrm{SD}=3.96)$ than did females $(\mathrm{M}=7.43, \mathrm{SD}$ $=3.82) ; t(77)=-3.20, \mathrm{p}=0.002$. Our results are not evidence of a biological cause for gender differences in spatial functioning, nor is there outside evidence of this (Newcombe and Stieff 2012). Because mental rotation ability is malleable (Uttal et al. 2013), training can successfully eliminate these differences in domainbased tasks. The literature also describes age-related differences on tests of working memory (Hambrick and Engle 2002) that our data confirm. Independent-sample $t$ tests demonstrated that participants under $25 \mathrm{yr}$ of age had higher working memory scores $(\mathrm{M}=24.15, \mathrm{SD}=$ $6.95)$ than did participants 25 and older $[\mathrm{M}=19.5, \mathrm{SD}$ $=6.95 ; t(65)=2.60, \mathrm{p}=0.012]$.

Using the Pearson correlation $(r)$, our measures of domain knowledge and expertise show moderate 
Table 3. Descriptive statistics for tests and tasks.

\begin{tabular}{|l|c|c|c|c|c|c|c|}
\hline & $\boldsymbol{N}$ & Minimum & Maximum & Mean & Std. Dev. & Skewness & Kurtosis \\
\hline $\begin{array}{l}\text { Hidden Figures Test } \\
\text { (disembedding) }\end{array}$ & 78 & 1 & 16 & 7.10 & 3.39 & 0.151 & -0.574 \\
\hline Mental Rotation Test & $77^{*}$ & 1 & 19 & 9.31 & 4.14 & -0.079 & -0.699 \\
\hline FMI (domain knowlege) & 78 & 11 & 34 & 26.03 & 5.81 & -0.573 & -0.699 \\
\hline $\begin{array}{l}\text { Matrix Span Test of } \\
\begin{array}{l}\text { Visuospatial Working } \\
\text { Memory }\end{array}\end{array}$ & $65^{* *}$ & 8 & 36 & 22.43 & 7.25 & -0.259 & -0.699 \\
\hline DEQ (expertise) & 78 & 0.75 & 11.75 & 4.66 & 3.34 & 0.741 & -0.902 \\
\hline Meteorology Taks & 78 & 9 & 35 & 26.03 & 5.81 & 0.124 & -0.048 \\
\hline
\end{tabular}

* One case was missing mental rotation data because of an incorrect test completion.

** The November 2016 data collection served as an initial pilot study of all tests except the Matrix Span Test of Visuospatial Working Memory. Therefore, for this measure only, $\mathrm{N}=65$.

correlation $(r=0.442, p<0.001)$, which confirms reasonable expectations and reinforces the validity of each measure. There is evidence that the meteorology task is a valid measure of skill as it correlates moderately with both expertise $(r=0.326, p=0.009)$ and domain knowledge $(r=0.545, p<0.001)$. The correlation between working memory and expertise is significant and negative $(r=-0.371, p=0.003)$ because of a strong correlation between expertise and age $(r=$ $0.784, p<0.001)$ and the aforementioned age-related differences on tests of working memory. Meteorology task performance positively correlates with domain knowledge $(r=0.545, p<0.001)$, expertise $(r=0.326$, $p=0.009)$, and disembedding $(r=0.280, p=0.025)$. The lack of significant correlation between working memory and the remaining variables is noteworthy and considered in the upcoming discussion section.

We performed a hierarchal regression analysis to determine the variance in meteorology task performance determined by the predictor variables. Because domain knowledge was a known predictor (Roebber and Bosart 1996) $)^{2}$ and the variable with the strongest correlation with the meteorology task, we entered it in step $1\left[\Delta R^{2}\right.$ $=0.284, \Delta F(1,76)=30.21, p<0.001]$. We entered the balance of the variables in step 2. In this step, only disembedding significantly predicted performance on the meteorology task $\left[\Delta R^{2}=0.054, \Delta F(1,75)=19.16, p\right.$ $<0.001]^{3}$. Additionally, expertise covaried with domain

\footnotetext{
${ }^{2}$ Roebber and Bosart (1996) found significant differences between subjects with high and low experience levels as subjectively assessed through evaluation of forecasters' familiarity with operational weather products, general forecasting experience, and intellectual curiosity about weather.
}

knowledge, thus it and the other predictors were not retained. The results of our final model are presented in Table 5. Meteorology knowledge accounts for $28 \%$ of the variance on the meteorology task, whereas disembedding, accounting for $5 \%$ of the variance, is a weak, but significant predictor. We cross-validated the model by verifying that the assumptions of linearity, homoscedasticity, independence, and normality were met. Appendix E contains plots of residuals to illustrate this, along with bivariate relationships to demonstrate that the predictors have reasonably linear relationships without obvious outliers.

To investigate the interplay between domain knowledge and disembedding, we performed a median split on the FMI score (domain knowledge) data and verified through an independent sample $t$ test a significant difference in the two groups' mean performance on the meteorology task $\left[\mathrm{M}_{\text {low }}=21.26\right.$, $\mathrm{SD}=4.20 ; \mathrm{M}_{\text {high }}=30.79, \mathrm{SD}=2.04 ; t(78)=-12.76$, $p<0.001]$. We created a scatterplot of disembedding regressed onto performance on the meteorology task by low and high domain-knowledge groups to illustrate that disembedding skill positively predicts performance on the meteorology task at both low and high levels of domain knowledge (see Fig. 1).

\footnotetext{
${ }^{3} \Delta R^{2}$ is the squared correlation between values of the outcome predicted by the model and values observed in the data, and represents the variance in the outcome explained by the model relative to how much variance exists (Field 2013). $\Delta \mathrm{F}$ is the change in the F-ratio, a measure of how much the model improved the predicted outcome compared to the level of inaccuracy of the model (Field 2013).
} 
Table 4. Correlations between variables.

\begin{tabular}{|l|c|c|c|c|c|c|}
\hline & Disembedding & $\begin{array}{c}\text { Mental } \\
\text { Rotation }\end{array}$ & $\begin{array}{c}\text { Domain } \\
\text { Knowledge }\end{array}$ & $\begin{array}{c}\text { Working } \\
\text { Memory }\end{array}$ & Expertise & $\begin{array}{c}\text { Meteorology } \\
\text { Task }\end{array}$ \\
\hline Disembedding $^{\mathbf{a}}$ & 1 & 0.153 & 0.127 & 0.233 & -0.061 & $0.280^{*}$ \\
\hline Mental Rotation $^{\mathbf{b}}$ & & 1 & $0.249^{*}$ & 0.204 & -0.058 & 0.076 \\
\hline Domain Knowledge $^{\mathrm{a}}$ & & & 1 & -0.061 & $0.442^{* *}$ & $0.545^{* *}$ \\
\hline Working Memory $^{\mathbf{c}}$ & & & & 1 & $-0.371^{* *}$ & -0.032 \\
\hline Expertise $^{\mathbf{a}}$ & & & & & 1 & $0.326^{* *}$ \\
\hline Meteorology Task $^{\mathbf{a}}$ & & & & & & 1 \\
\hline
\end{tabular}

* Correlation is significant at the 0.05 level ( 2 tailed). ${ }^{* *}$ Correlation is significant at the 0.01 level ( 2 tailed). ${ }^{\mathrm{a}} \mathrm{N}=78 ;{ }^{\mathrm{b}} \mathrm{N}=77 ;{ }^{\mathrm{c}} \mathrm{N}=65$

Table 5. Results of hierarchal regression analysis predicting performance on meteorology tasks.

\begin{tabular}{|l|c|c|c|c|}
\hline \multicolumn{1}{|c|}{ Variable } & $\boldsymbol{\Delta R}^{\mathbf{a}}$ & $\boldsymbol{B}^{\mathbf{b}}$ & $\boldsymbol{\Delta F}^{\mathbf{c}}$ & $\mathbf{d f}^{\mathbf{d}}$ \\
\hline $\begin{array}{l}\text { Step 1 } \\
\text { Domain Knowledge }\end{array}$ & 0.284 & 0.494 & $30.21^{*}$ & 1,76 \\
\hline $\begin{array}{l}\text { Step 2 } \\
\text { Disembedding }\end{array}$ & 0.054 & 0.235 & $19.16^{*}$ & 1,75 \\
\hline Total Adjusted $\mathbf{R}^{\mathbf{2}}$ & 0.338 & & & \\
\hline
\end{tabular}

$\mathrm{N}=78 ; *=\mathrm{p}<0.001$

${ }^{\mathrm{a}}$ Variance in the outcome; ${ }^{\mathrm{b}}$ beta; ${ }^{\mathrm{c}} \mathrm{F}-\mathrm{ratio} ;{ }^{\mathrm{d}}$ degrees of freedom

\section{Discussion}

Returning to our research question, we asked, "What effects do working memory, domain knowledge, mental rotation, disembedding, and expertise have on performance on a series meteorology tasks?". We found that domain knowledge and disembedding skill predict performance on the tasks. Our finding that domain knowledge is the strongest predictor is not surprising and aligns with the results of other studies (e.g., Hegarty et al. 2010). It also is not surprising that domain knowledge and expertise are moderately correlated $(\mathrm{r}=$ $0.442, p<0.001$ ); in reality, they are inextricably related. Roebber and Bosart (1996) examined the contributions of both education and experience to weather forecasting skill and noted "that the distinction between education and experience is not precise...students can gain experience through the study of particular cases in a synoptic lab" (p. 27). In their analysis of nine semesters of forecast contest data, Roebber and Bosart determined that the primary advantage maintained by an experienced forecaster is the larger set of cases from which they may draw information. They propose that experienced forecasters are in a better position to recognize patterns in current weather data or notice deviations from a pattern and act accordingly. This is possibly the advantage held by our participants with high levels of meteorology knowledge as well. By virtue of their higher knowledge level, they have been exposed to a greater number of weather scenarios, including the classic midlatitude cyclone featured in the meteorology task. Recognition of this weather pattern by successful participants likely prompted them to chunk data and seek patterns associated with this type of weather scenario in the surface and upper-air maps.

Identification of disembedding as a significant predictor of performance on the meteorology task is an additional and exciting finding. Especially interesting is that disembedding has a positive effect at both low and high levels of meteorology knowledge. This is in contrast to a similar study done in a geology context using performance on a bedrock mapping task as an outcome variable (see Hambrick et al. 2012). Here, researchers found that participants were able to overcome limitations in spatial ability with higher levels of geology knowledge. Why this difference exists is potentially captured by a statement from their paper: "We speculate that another potentially important factor is whether the task input is static or dynamic" (p. 6). In other words, in the case of geologic mapping, the input 


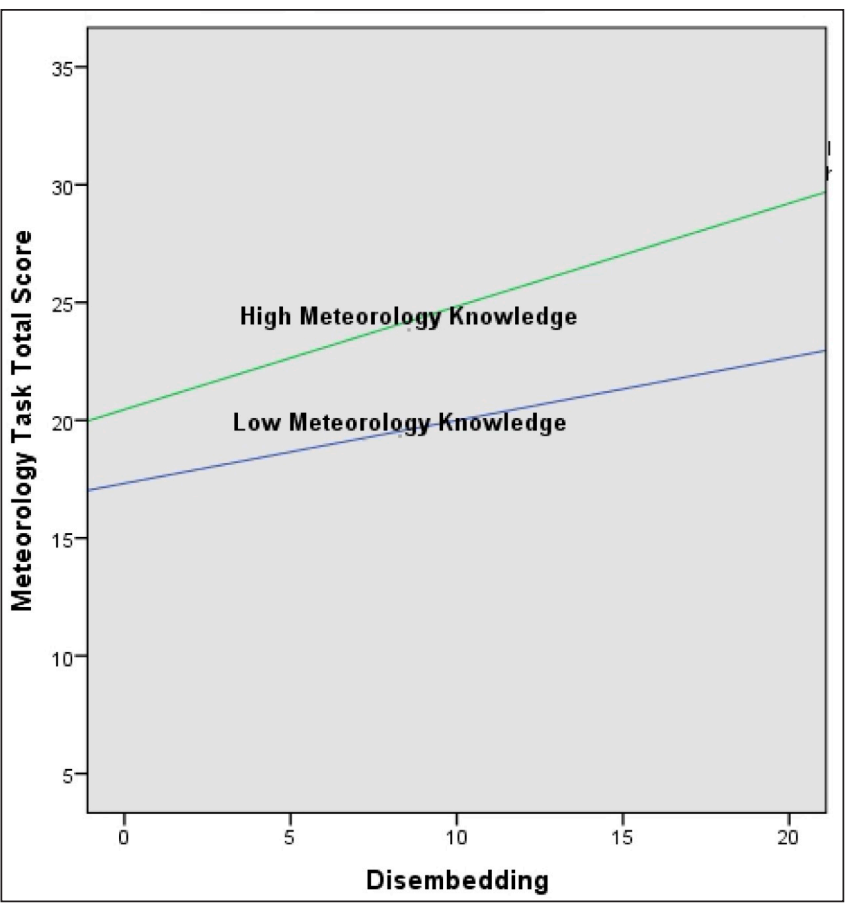

Figure 1. Correlations between variables. Click image for an external version; this applies to all figures hereafter.

does not change over time, thus individuals can encode information in long-term memory and potentially bypass the need to think spatially or rely on other cognitive skills. However, when solving meteorological problems, individuals necessarily deal with constantly changing input - the weather - and may need to rely on relevant cognitive skills, such as disembedding, with each new task. Investigating how disembedding ability may interplay with the need to constantly reinterpret data is an interesting line of research that we hope to pursue with future work.

The remaining cognitive factors (mental rotation and working memory) were not significant predictors of performance on the meteorology task. Considering that their inclusion was theoretically informed, this is surprising and we are compelled to contemplate why. The aforementioned study (Hambrick et al. 2012) demonstrated a significant spatial visualization effect on the ability to create accurate geologic maps, presumably because the ability is important for mentally deconstructing a folded and faulted landscape. We investigated the same effect with meteorologists, who hypothetically visualize atmospheric dynamics, and found none. Our results suggest instead that our participants used spatial skills to interpret complex data displays rather than visualize atmospheric motion.
Mental visualization requires holding configurations in mind and taxes the working memory, and this may compete with the meteorologist's need to interpret multiple data displays and complex imagery-both physical and computerized.

It also may be that the mental rotation test, which involves rotating a rigid solid, does not align well with skills that meteorologists use to visualize atmospheric motion. If indeed meteorologists employ this type of visualization and are skilled with it, a test that assesses the ability to visualize fluid dynamics would better predict an effect of this skill on the meteorology tasks. Unfortunately, we are unaware of such a test. However, Atit et al. (2013) developed and administered a non-rigid (plastic) mental transformation test involving bending rather than rotating. They compared results of this test to results on the Vandenberg and Kuse Test of Mental Rotation and found that the results did not strongly correlate with each other. This suggests that spatial skills used for non-rigid (plastic) mental bending are distinct from spatial skills used for rigid mental rotation, such as those assessed by the Vandenberg and Kuse Test of Mental Rotation. Considering that their test involved visualizing plastic transformation, our investigation into visualizing fluid motion represents an even further distanced degree of rigidity (or lack thereof) from rigid mental rotation. However, given test availability, the Vandenberg and Kuse Test was a good place to start. Continuing to investigate these differences represents a fascinating line of future research.

In the case of working memory, our results demonstrated a significant difference in scores by age, drawing the validity of our working memory results into question. Additionally, working memory capacity is context specific and our task may not have provided adequate context for demonstrating a working memory effect. Joslyn and Jones (2008) used a naturalistic design in their analysis of verbal protocol produced by naval weather forecasters in an operational setting. Their results suggest that the time-pressured and interrupted environment in which these forecasters work creates additional load on working memory that limits the ability to create and maintain complex mental representation of atmospheric conditions. By designing a meteorology task that stresses working memory to a greater degree and administering it within a homogenous age group, in a naturalistic setting, we may create a better opportunity to elicit and measure such an effect, if present. The addition of multiple types of complex-span tests of working memory (visuospatial, verbal, and arithmetic) 
may additionally capture a more nuanced depiction of participants' working memory.

\section{Conclusions and future research}

Our study provides evidence that disembedding is a skill that predicts performance on typical meteorology problems required of undergraduate meteorology students. Additionally, disembedding skill positively affects meteorology skill with student (low knowledge) meteorologists as well as experienced (high knowledge) meteorologists. The advantage appears to lie in the ability to identify patterns, be they embedded in distracting background displays, repeated in weather scenarios, or present in observational data. We propose that there is value simply in raising awareness of the potential limitations of low disembedding meteorologists and meteorology students so that it is recognized as a potential source of misunderstanding; not all individuals are able to detect patterns that may be immediately apparent to others. Targeted disembedding training and practice with pattern identification within a meteorology classroom may yield positive results. This is another area ripe for future research.

Ourfindings corroborate previous research (Roebber and Bosart 1996) and support evidence claiming that meteorology knowledge and expertise are the strongest predictors of performance on typical meteorology problems required of undergraduate meteorology students. Therefore, meteorology training that provides frequent and sustained practice using realistic forecasting scenarios to build knowledge and expertise, is likely the strongest foundation for supporting the development of critical pattern recognition skills.

As an early study situated at the intersection of cognitive science and discipline-based education research in meteorology, we hope that our work will serve as a springboard for subsequent research. The potential for impacting the field is great, including the development of new learning interventions to inform meteorology education communities broadly, encompassing university meteorology courses for majors and non-majors, military weather forecaster preparation, and professional training for operational meteorologists.

Acknowledgments: This research was funded by the Graduate College at Western Michigan University. In addition to our participants, we owe a debt of gratitude to Dr. Teresa Bals-Elsholz, who graciously shared her content knowledge, expertise, and students in support of this project. We additionally thank Dr. David Changnon, Dr. Sandra Yuter, Dr. William Burnett, John Dumas, and Dr. Walker Ashley for facilitating access to study participants. Finally, we appreciate the Plymouth State Weather Center for permitting us to use and publish their weather maps. 


\section{APPENDIX A}

\section{Domain Experience Questionnaire}

This survey is intended to summarize your education, training, and current employment experience in atmospheric science and meteorology. Please respond to all items that apply as of the current date.

1. Do you primarily consider yourself to be a(n) (circle please)

Atmospheric scientist Operational meteorologist

Broadcast meteorologist Climatologist

Other (fill in)

2. Do you currently work in (circle please)

Academia Industry Government Military Student $\quad$ Other (fill in)

3. What is your specific area of expertise? (If you have expertise in more than one area, please circle your

primary area of expertise.)

Remote sensing Weather analysis and forecasting Climate change and variability

Climate modeling Severe weather Other

4. For how many years have you been working in your primary area of expertise, not including your education? (circle please; N/A if you are a student)
N/A
$0-5$
$6-10$
$11-15$
$16-20$
$21-25$
$>25$

5. In your daily practice, how often do you engage in the following activities? (circle please)

a. Interpreting/analyzing surface and upper-air data (not including model forecasts)

Often Sometimes Rarely Never

b. Using model output for weather/climate prediction

Often Sometimes Rarely Never

c. Communicating weather/climate information to the public

Often Sometimes Rarely Never

d. Writing research papers, reports, reviews, and summaries related to weather/climate

Often Sometimes Rarely Never

6. How often have you worked in the following domains? (circle please)

a. Midlatitude and polar weather systems

Often Sometimes Rarely Never

b. Tropical weather systems

Often Sometimes Rarely Never

c. Mesoscale weather systems

Often Sometimes Rarely Never

d. Weather observing, analysis, and diagnosis

Often Sometimes Rarely Never

e. Weather forecasting

Often Sometimes Rarely Never 
APPENDIX A (continued)

7. Have you completed any of the following military training? (please check yes or no)

\begin{tabular}{|l|c|c|}
\hline & YES & NO \\
\hline Aeographer's Mate A School (U.S. Navy) & & \\
\hline Aeographer's Mate A School (U.S. Navy) & & \\
\hline Officer Basic Meteorology Program (U.S. Air Force) & & \\
\hline Air Force Enlisted Weather Specialist Training & & \\
\hline
\end{tabular}

8. Did you take, or are you taking, any of the following college-level courses? (please check yes or no)

\begin{tabular}{|l|l|l|}
\hline & YES & NO \\
\hline Introduction to Weather Analysis & & \\
\hline Synoptic Meteorology & & \\
\hline Dynamic Meteorology & & \\
\hline Mesoscale Meteorology & & \\
\hline Physical Meteorology & & \\
\hline Climatology & & \\
\hline Forecasting & & \\
\hline Broadcast Meteorology & & \\
\hline
\end{tabular}

9. Have you completed or are you currently working on (please check yes or no)

\begin{tabular}{|c|c|c|}
\hline & YES & NO \\
\hline An assistantship or internship in atmospheric science or a related field & & \\
\hline $\begin{array}{l}\text { Any original research in atmospheric science or a related field, including an } \\
\text { undergraduate thesis or research project in a course }\end{array}$ & & \\
\hline
\end{tabular}

Please check yes or no:

\begin{tabular}{|l|l|l|}
\hline \multicolumn{1}{|c|}{ YES } & NO \\
\hline 10. Are you currently pursuing an M.A./M.S. in atmospheric science or a related field? & & \\
\hline 11. Do you hold an M.A./M.S. in atmospheric science or a related field? & & \\
\hline 12. Are you currently pursuing a Ph.D. in atmospheric science or a related field? & & \\
\hline 13. Do you hold a Ph.D. in atmospheric science or a related field? & & \\
\hline 14. Are you an AMS Certified Broadcast Meteorologist? & & \\
\hline 15. Are you an AMS Certified Consulting Meteorologist? & & \\
\hline 16. Have you earned the AMS Seal of Approval? & & \\
\hline 17. Do you currently, or have you ever, worked professionally as a meteorologist? & & \\
\hline
\end{tabular}

If you answered yes to number 17, how many years did you, or have you, worked as a professional meteorologist? (please circle)

$<5 \mathrm{yr} \quad 5-10 \mathrm{yr} \quad>10 \mathrm{yr}$ 
APPENDIX A (continued)

18. Please use the space below to tell us anything else important about your prior experiences in operational meteorology, weather forecasting, broadcast meteorology, and/or the local weather of your region.

\section{DEMOGRAPHICS}

19. What is your gender? (circle please)

Male Female Transgender

20. What is your age?

21. What is your home state or territory?

22. What is your race/ethnicity? PLEASE MARK ALL THAT APPLY

$\begin{array}{lllllll}\square & \text { African American/Black } & \text { Caucasian } & \square & \text { Latino/Hispanic } & \square & \text { Native American } \\ \square & \text { Asian/Native Hawaiian/Pacific Islander } & \text { Other } & & \end{array}$




\section{APPENDIX B}

\section{Series of Meteorology Tasks}
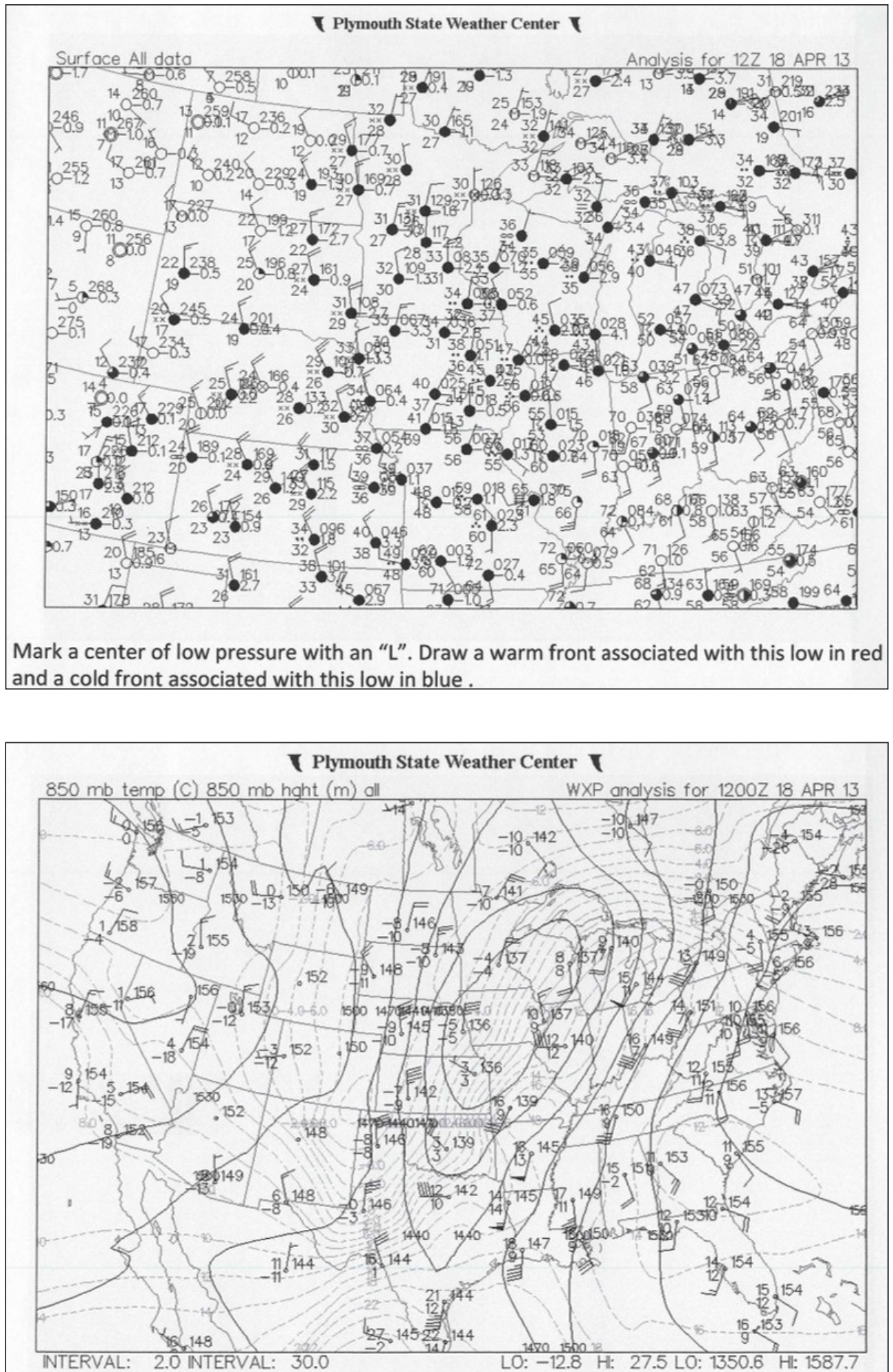

Mark the location of all trough axes with dashed lines and all ridge axes with zigzagged lines. Shade areas of warm air advection in red and cold air advection in blue. 
APPENDIX B (continued)
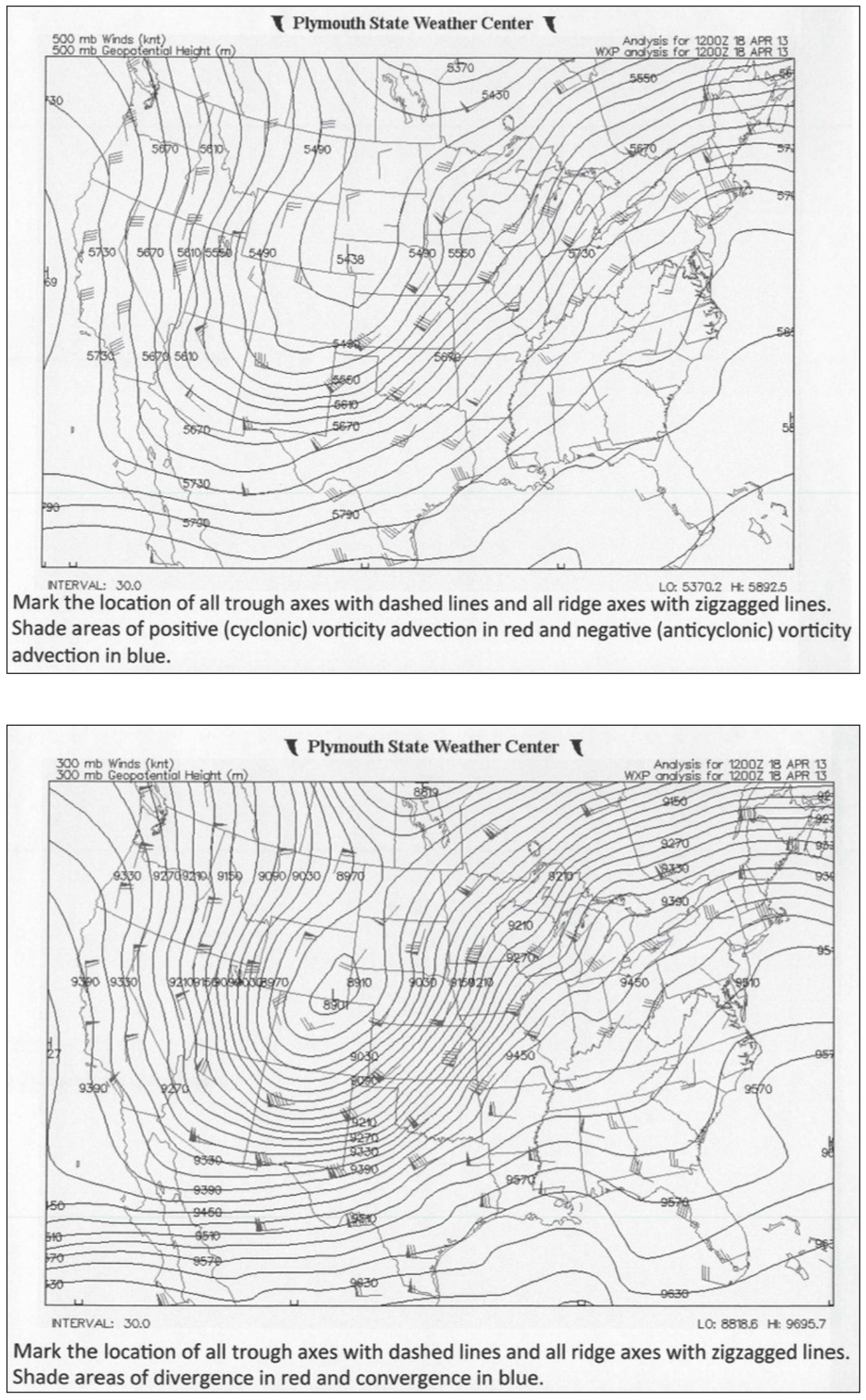
APPENDIX B (continued)

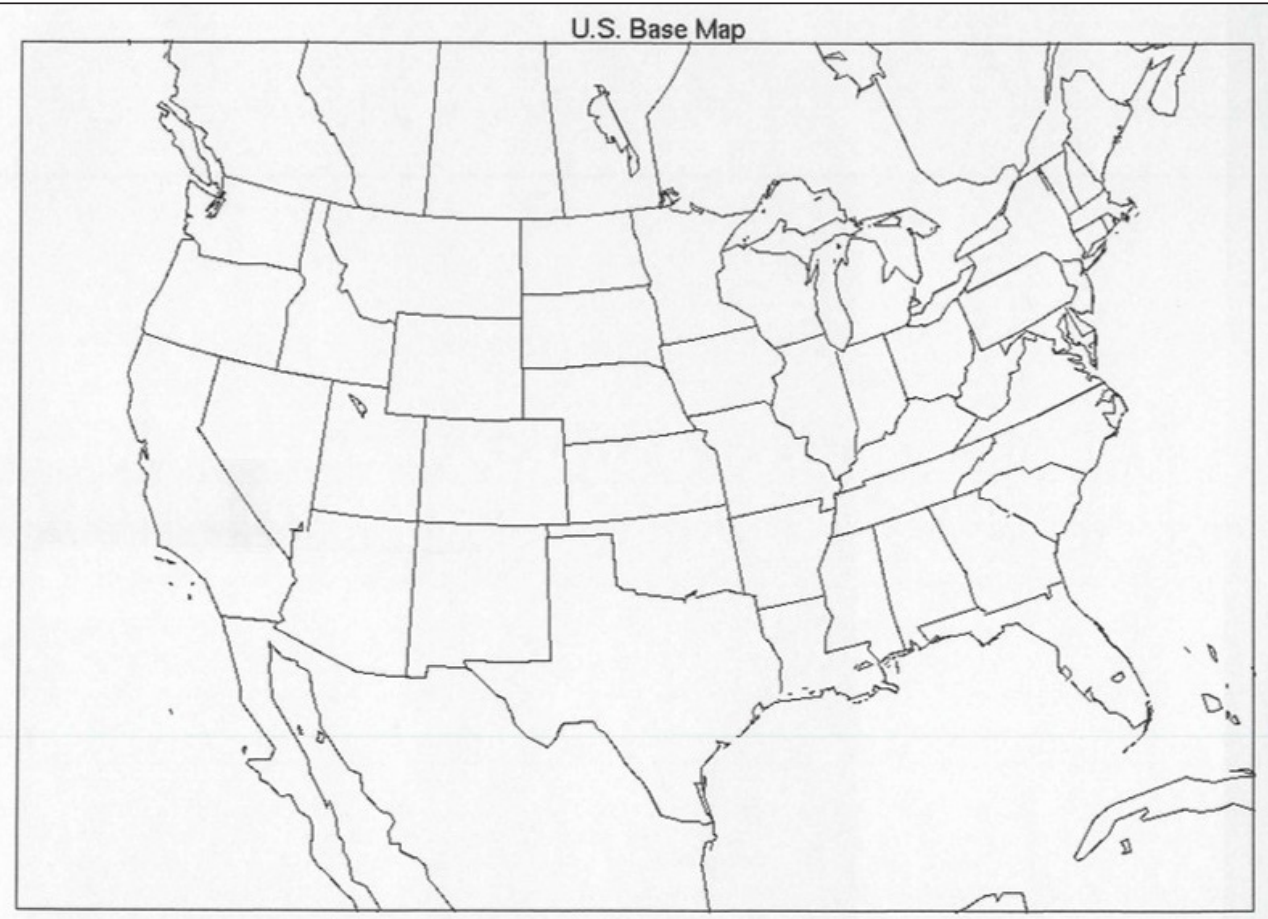

Based on the information in the preceding images, predict the location of the surface low 12 hours from the time of the images and indicate its location on the map with an " $\mathrm{L}$ ". 


\section{APPENDIX C}

\section{Scoring Rubric for Series of Meteorology Tasks}

1. Surface map

Novice Some skill Medium skill Advanced Expert

\begin{tabular}{|l|l|l|l|l|l|l|l|l|l|}
\hline $\begin{array}{l}\text { Low, } \\
\text { cold } \\
\text { front, } \\
\text { warm } \\
\text { front in } \\
\text { wrong } \\
\text { place or } \\
\text { missing }\end{array}$ & $\begin{array}{l}\text { wrong } \\
\text { place, } \\
\text { cold front } \\
\text { partiaced, } \\
\text { warm } \\
\text { front }\end{array}$ & $\begin{array}{l}\text { low, front } \\
\text { not with } \\
\text { wind } \\
\text { field, or } \\
\text { partial } \\
\text { warm } \\
\text { front }\end{array}$ & $\begin{array}{l}\text { low area } \\
\text { (MO), } \\
\text { cold front } \\
\text { displaced, } \\
\text { Partial } \\
\text { warm } \\
\text { front }\end{array}$ & $\begin{array}{l}\text { low area, } \\
\text { Cold front, } \\
\text { warm } \\
\text { front } \\
\text { extends } \\
\text { in straight } \\
\text { line }\end{array}$ & $\begin{array}{l}\text { Primary } \\
\text { low } \\
\text { area, } \\
\text { cold } \\
\text { front, } \\
\text { partial } \\
\text { warm } \\
\text { front }\end{array}$ & $\begin{array}{l}\text { Primary } \\
\text { low, } \\
\text { Cold front, } \\
\text { Warm } \\
\text { front } \\
\text { extends } \\
\text { north and } \\
\text { east }\end{array}$ & $\begin{array}{l}\text { Lowest, } \\
\text { Cold } \\
\text { front, } \\
\text { Warm } \\
\text { front } \\
\text { extends } \\
\text { north } \\
\text { along } \\
\text { pressure } \\
\text { trough }\end{array}$ & $\begin{array}{l}\text { Lowest } \\
\text { low, } \\
\text { Cold } \\
\text { front, } \\
\text { Warm } \\
\text { front } \\
\text { extends } \\
\text { north and } \\
\text { east with } \\
\text { wind } \\
\text { field }\end{array}$ & $\begin{array}{l}\text { Lowest } \\
\text { low, } \\
\text { cold } \\
\text { front, } \\
\text { complex } \\
\text { warm } \\
\text { front }\end{array}$ \\
\hline 1 & 2 & 3 & 4 & 5 & 6 & 7 & 8 & 9 & 10 \\
\hline
\end{tabular}

Note: Expert disagrees with NCEP/WPC analysis on warm front. Mid-60 temps with south winds are south of warm front (WPC had north of warm front in Ohio). Analysis from WPC may have been based on continuity from prior time period analysis. Zero for a blank map.

Novice example, surface map (click image to enlarge).

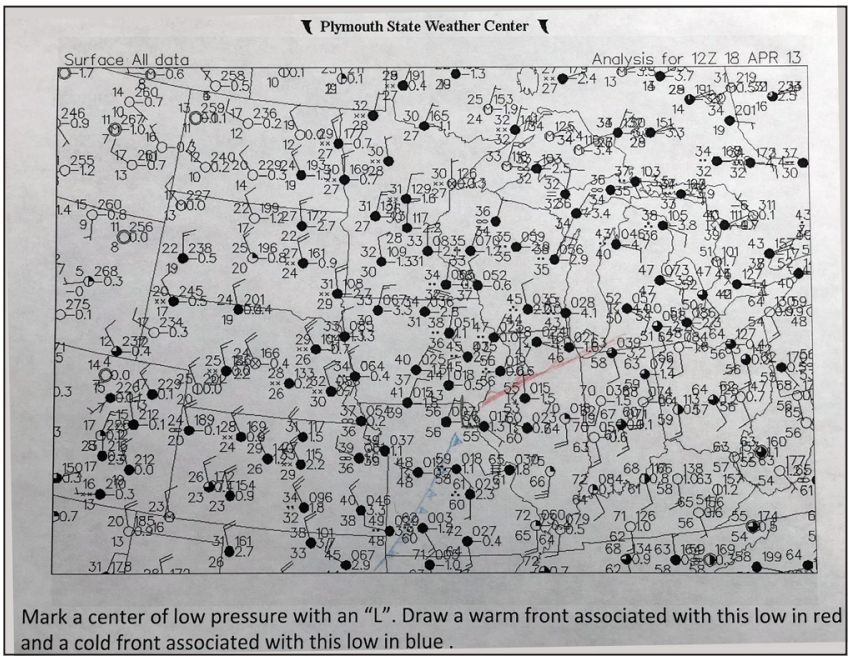

Expert example, surface map (click image to enlarge).

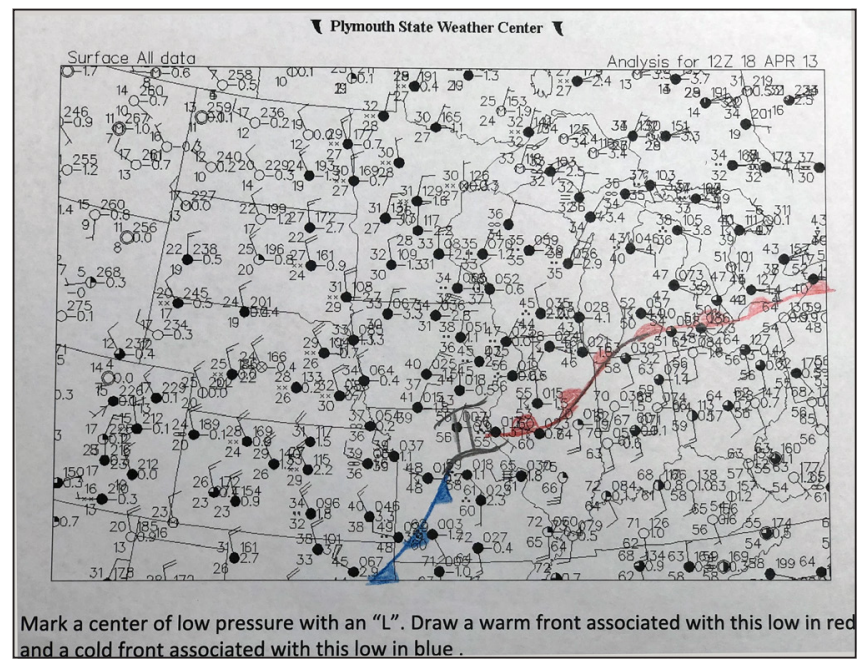


APPENDIX C (continued)

2. $850-\mathrm{hPa}$ map

Novice Some skill Medium skill Advanced Expert

\begin{tabular}{|c|c|c|c|c|c|c|c|c|c|}
\hline $\begin{array}{l}\text { Missed } \\
\text { locations } \\
\text { of } \\
\text { trough/ } \\
\text { ridge } \\
\text { CAA } \\
\text { with } \\
\text { cold air } \\
\text { center, } \\
\text { WAA } \\
\text { with } \\
\text { warm air } \\
\text { center }\end{array}$ & $\begin{array}{l}\text { Main } \\
\text { trough } \\
\text { with } \\
\text { low and } \\
\text { ridge, } \\
\text { CAA } \\
\text { west } \\
\text { of low, } \\
\text { WAA } \\
\text { east of } \\
\text { low }\end{array}$ & $\begin{array}{l}\text { Main } \\
\text { trough } \\
\text { with low } \\
\text { and ridge, } \\
\text { some } \\
\text { CAA with } \\
\text { north } \\
\text { winds, } \\
\text { some } \\
\text { WAA } \\
\text { with south } \\
\text { winds }\end{array}$ & $\begin{array}{l}\text { Main } \\
\text { trough } \\
\text { and } \\
\text { ridge, } \\
\text { CAA } \\
\text { with } \\
\text { north } \\
\text { winds, } \\
\text { WAA } \\
\text { with } \\
\text { south } \\
\text { winds }\end{array}$ & $\begin{array}{l}\text { Main } \\
\text { trough } \\
\text { and } \\
\text { ridge, } \\
\text { CAA/ } \\
\text { WAA } \\
\text { with } \\
\text { major } \\
\text { temp } \\
\text { gradients }\end{array}$ & $\begin{array}{l}\text { Main } \\
\text { troughs } \\
\text { and } \\
\text { ridges, a } \\
\text { few short } \\
\text { waves, } \\
\text { major } \\
\text { areas and } \\
\text { some } \\
\text { smaller } \\
\text { areas of } \\
\text { CAA/ } \\
\text { WAA }\end{array}$ & $\begin{array}{l}\text { Some } \\
\text { short } \\
\text { waves, } \\
\text { CAA \& } \\
\text { WAA } \\
\text { analyzed } \\
\text { across } \\
\text { map }\end{array}$ & $\begin{array}{l}\text { Short } \\
\text { waves, } \\
\text { no areas } \\
\text { of CAA/ } \\
\text { WAA } \\
\text { where } \\
\text { isotherms } \\
\text { parallel } \\
\text { to flow }\end{array}$ & $\begin{array}{l}\text { Short } \\
\text { waves, } \\
\text { no areas } \\
\text { of CAA/ } \\
\text { WAA } \\
\text { where } \\
\text { isotherms } \\
\text { parallel } \\
\text { to flow, } \\
\text { caught } \\
\text { WAA on } \\
\text { backside } \\
\text { of low }\end{array}$ & $\begin{array}{l}\text { Multiple } \\
\text { short } \\
\text { waves, } \\
\text { subtle } \\
\text { WAA/ } \\
\text { CAA } \\
\text { details, } \\
\text { caught obs } \\
\text { different } \\
\text { than geos } \\
\text { advections }\end{array}$ \\
\hline 1 & 2 & 3 & 4 & 5 & 6 & 7 & 8 & 9 & 10 \\
\hline
\end{tabular}

Note: Some analysts marked the thermal trough and ridge. Zeros for completely missed trough/ridge axes and CAA/WAA not in proper areas or even associated with cold/warm air masses.

Novice example, 850-hPa map (click image to enlarge).

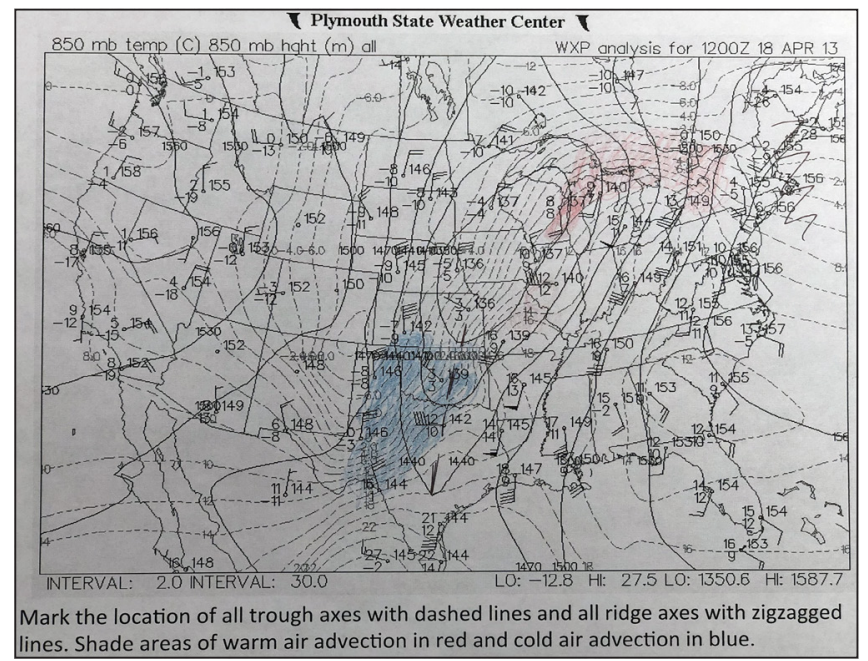

Expert example, 850-hPa map (click image to enlarge).

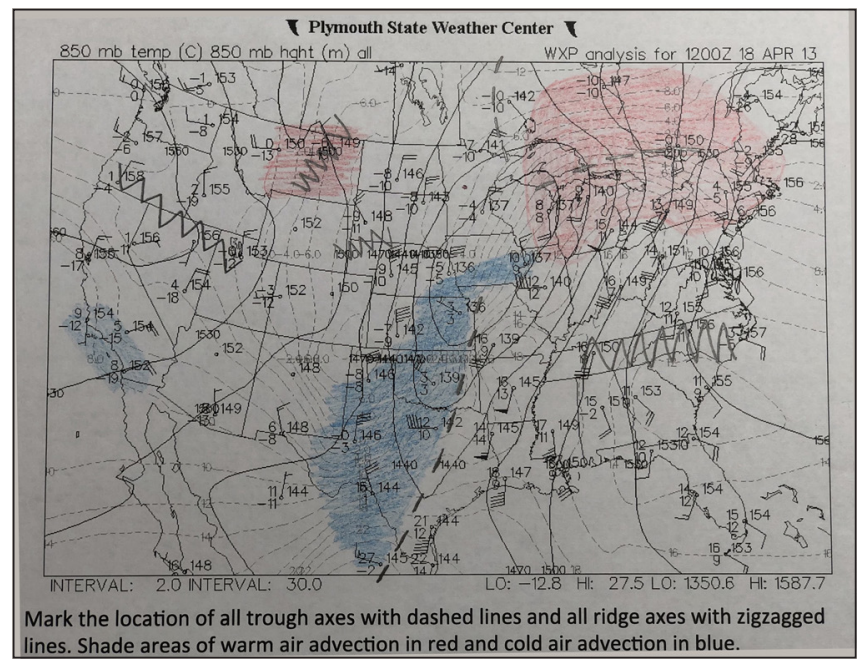


APPENDIX C (continued)

3. 500-hPa map

Novice Some skill Medium skill Advanced Expert

\begin{tabular}{|c|c|c|c|c|c|c|c|c|c|}
\hline $\begin{array}{l}\text { Missed } \\
\text { main } \\
\text { trough \& } \\
\text { ridge, } \\
\text { CVA } \\
\text { with low } \\
\text { center, } \\
\text { AVA } \\
\text { with } \\
\text { high } \\
\text { center }\end{array}$ & $\begin{array}{l}\text { Main } \\
\text { trough } \\
\text { and } \\
\text { ridge, } \\
\text { CVA } \\
\text { with } \\
\text { trough } \\
\text { center, } \\
\text { AVA } \\
\text { with } \\
\text { ridge } \\
\text { center }\end{array}$ & $\begin{array}{l}\text { Main } \\
\text { trough } \\
\text { and } \\
\text { ridge, } \\
\text { minimal } \\
\text { areas of } \\
\text { CVA/ } \\
\text { AVA } \\
\text { east/west } \\
\text { of trough }\end{array}$ & $\begin{array}{l}\text { Main } \\
\text { trough } \\
\text { \& ridge, } \\
\text { broad } \\
\text { areas of } \\
\text { CVA/ } \\
\text { AVA } \\
\text { east/west } \\
\text { low, AVA } \\
\text { east/west } \\
\text { of ridge }\end{array}$ & $\begin{array}{l}\text { Main } \\
\text { trough } \\
\text { and } \\
\text { ridge, } \\
\text { CVA/ } \\
\text { AVA } \\
\text { east/ } \\
\text { west of } \\
\text { trough/ } \\
\text { ridge }\end{array}$ & $\begin{array}{l}\text { Main } \\
\text { troughs } \\
\text { and } \\
\text { ridges, a } \\
\text { few short } \\
\text { waves, } \\
\text { major } \\
\text { areas of } \\
\text { CVA/ } \\
\text { AVA }\end{array}$ & $\begin{array}{l}\text { Some } \\
\text { short } \\
\text { waves, } \\
\text { CVA } \\
\text { \& AVA } \\
\text { analyzed } \\
\text { across } \\
\text { map }\end{array}$ & $\begin{array}{l}\text { Short } \\
\text { waves, } \\
\text { no areas } \\
\text { of CVA/ } \\
\text { AVA in } \\
\text { trough/ } \\
\text { ridge } \\
\text { lines }\end{array}$ & $\begin{array}{l}\text { Short } \\
\text { waves, } \\
\text { multiple } \\
\text { areas of } \\
\text { CVA/AVA } \\
\text { with each } \\
\text { trough/ } \\
\text { ridge }\end{array}$ & \begin{tabular}{|l} 
Multiple \\
short- \\
wave \\
troughs \\
\& ridges, \\
subtle \\
CVA/AVA \\
details
\end{tabular} \\
\hline 1 & 2 & 3 & 4 & 5 & 6 & 7 & 8 & 9 & 10 \\
\hline
\end{tabular}

Novice example, 500-hPa map (click image to enlarge).

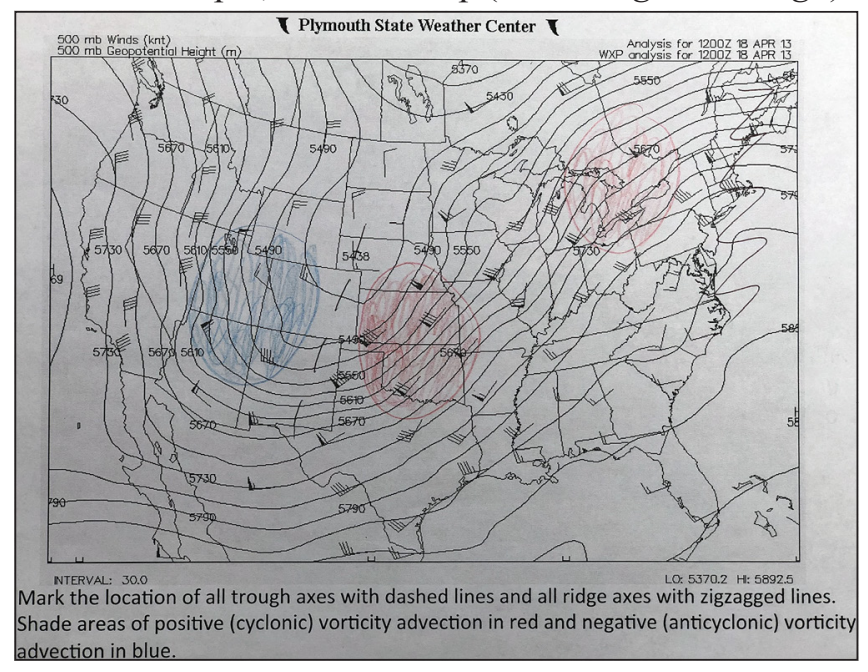

Expert example, 500-hPa map (click image to enlarge).

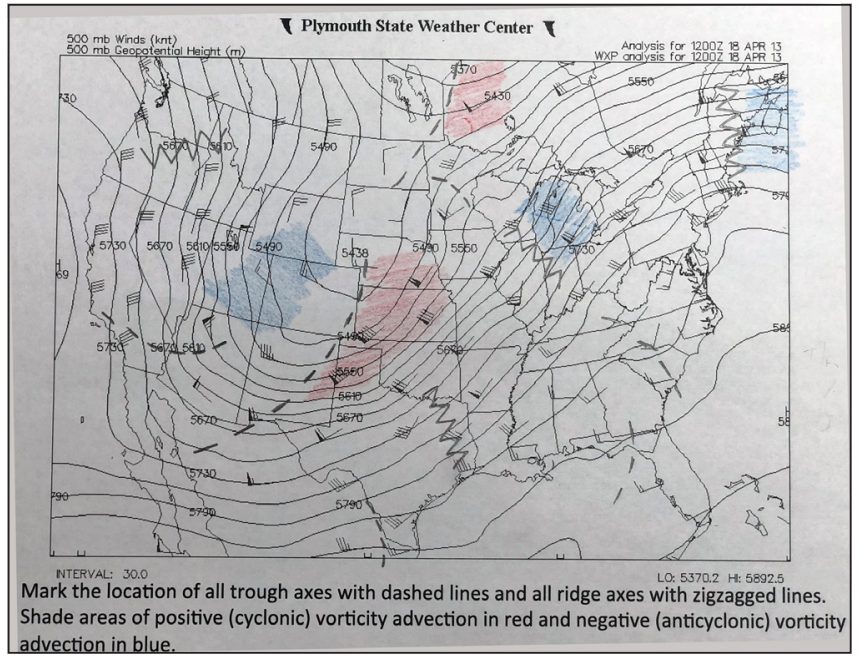


APPENDIX C (continued)

4. 300-hPa map

Novice Some skill Medium skill Advanced Expert

\begin{tabular}{|c|c|c|c|c|c|c|c|c|c|}
\hline $\begin{array}{l}\text { Main } \\
\text { trough } \\
\text { due north/ } \\
\text { south, } \\
\text { Conv } \\
\text { in low } \\
\text { center, } \\
\text { div } \\
\text { misplaced }\end{array}$ & $\begin{array}{l}\text { Main } \\
\text { trough } \\
\text { and ridge } \\
\text { located, } \\
\text { but still } \\
\text { more } \\
\text { north/ } \\
\text { south } \\
\text { oriented, } \\
\text { conv in } \\
\text { center } \\
\text { of low, } \\
\text { div over } \\
\text { ridge } \\
\text { center }\end{array}$ & $\begin{array}{l}\text { More } \\
\text { than } \\
\text { one } \\
\text { trough } \\
\text { and } \\
\text { ridge, } \\
\text { conv } \\
\text { into } \\
\text { trough, } \\
\text { div } \\
\text { out of } \\
\text { trough }\end{array}$ & $\begin{array}{l}\text { Main } \\
\text { trough } \\
\text { and } \\
\text { ridge, } \\
\text { multiple } \\
\text { areas of } \\
\text { conv/div }\end{array}$ & $\begin{array}{l}\text { Main } \\
\text { trough } \\
\text { and } \\
\text { ridge, } \\
\text { broad } \\
\text { areas of } \\
\text { conv/div } \\
\text { analyzed }\end{array}$ & $\begin{array}{l}\text { Main } \\
\text { troughs } \\
\text { and ridges, } \\
\text { some short } \\
\text { waves, } \\
\text { major areas } \\
\text { of conv/div, } \\
\text { with other } \\
\text { areas also } \\
\text { analyzed, } \\
\text { do not cross } \\
\text { trough/ } \\
\text { ridge lines }\end{array}$ & $\begin{array}{l}\text { Some } \\
\text { short } \\
\text { waves, } \\
\text { conv } \\
\& \text { div } \\
\text { analyzed } \\
\text { across } \\
\text { map }\end{array}$ & $\begin{array}{l}\text { Short } \\
\text { waves, } \\
\text { flow } \\
\text { pattern } \\
\text { of conv/ } \\
\text { div } \\
\text { located } \\
\text { even } \\
\text { across } \\
\text { trough } \\
\text { and ridge } \\
\text { lines }\end{array}$ & $\begin{array}{l}\text { Short } \\
\text { waves in } \\
\text { troughs } \\
\text { \& ridges, } \\
\text { speed } \\
\text { conv/div } \\
\text { considered } \\
\text { as well } \\
\text { as flow } \\
\text { pattern }\end{array}$ & $\begin{array}{l}\text { Multiple } \\
\text { short } \\
\text { waves } \\
\text { for } \\
\text { troughs } \\
\text { \& ridges, } \\
\text { subtle } \\
\text { conv/div } \\
\text { details } \\
\text { for speed } \\
\text { and flow }\end{array}$ \\
\hline 1 & 2 & 3 & 4 & 5 & 6 & 7 & 8 & 9 & 10 \\
\hline
\end{tabular}

Novice example, 300-hPa map (click image to enlarge).

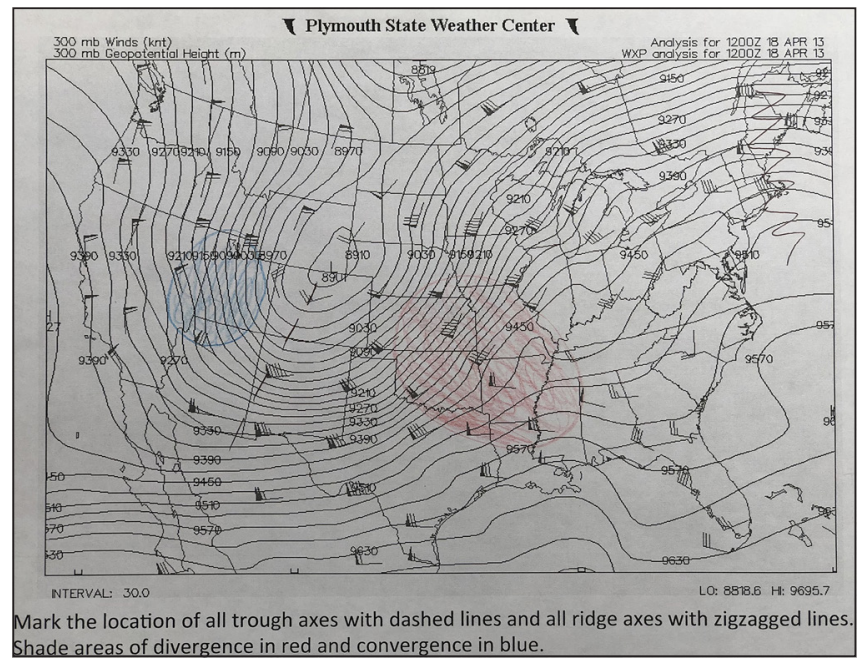

Expert example, 300-hPa map (click image to enlarge).

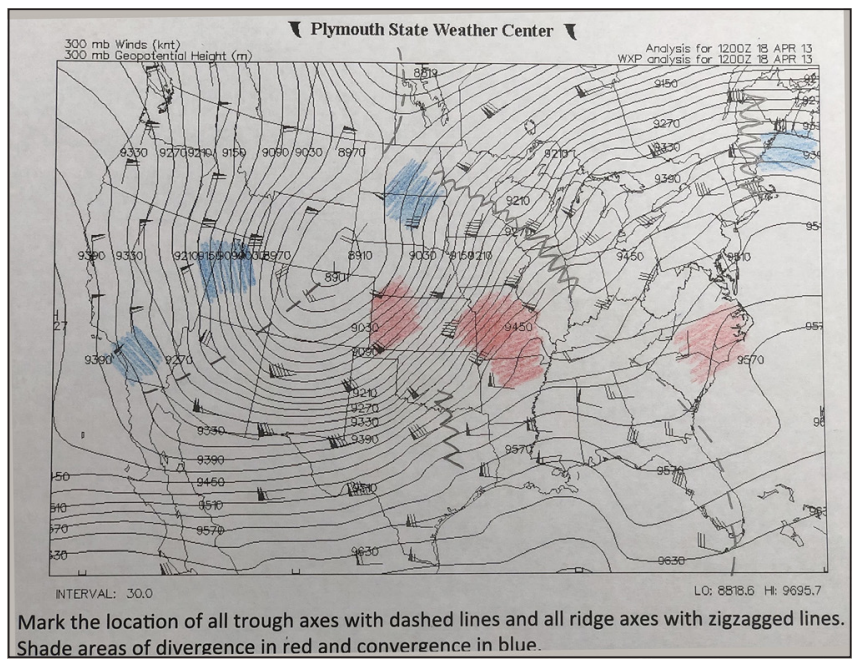


APPENDIX C (continued)

5. Forecast low position
Novice
Some skill
Medium skill
Advanced
Expert

\begin{tabular}{|l|l|l|l|l|l|l|l|l|l|}
\hline $\begin{array}{l}\text { Low } \\
\text { did not } \\
\text { move }\end{array}$ & $\begin{array}{l}\text { Low } \\
\text { moved } \\
\text { west or } \\
\text { south }\end{array}$ & $\begin{array}{l}\text { Low } \\
\text { moved an } \\
\text { unrealistic } \\
\text { distance } \\
\text { east }\end{array}$ & $\begin{array}{l}\text { Low } \\
\text { moved } \\
\text { due east }\end{array}$ & $\begin{array}{l}\text { Low } \\
\text { moved } \\
\text { unrealistic } \\
\text { distance } \\
\text { N }\end{array}$ & $\begin{array}{l}\text { Low } \\
\text { moved } \\
\text { N or NE } \\
\text { but not in } \\
\text { WAA }\end{array}$ & $\begin{array}{l}\text { Low } \\
\text { moved } \\
\text { Nor NE } \\
\text { but not in } \\
\text { CVA or } \\
\text { DIV }\end{array}$ & $\begin{array}{l}\text { Low } \\
\text { moved N } \\
\text { or NE but } \\
\text { not in one } \\
\text { of 3 areas }\end{array}$ & $\begin{array}{l}\text { Low } \\
\text { moved N } \\
\text { or NE but } \\
\text { not far } \\
\text { enough }\end{array}$ & $\begin{array}{l}\text { Low } \\
\text { moved N } \\
\text { coincident } \\
\text { with max } \\
\text { WAA/ } \\
\text { CVA/DIV } \\
\text { aloft and } \\
\text { SW flow } \\
\text { WI or MI }\end{array}$ \\
\hline 1 & 2 & 3 & 4 & 5 & 6 & 7 & 8 & 9 & 10 \\
\hline
\end{tabular}

Novice example, base map (click image to enlarge).

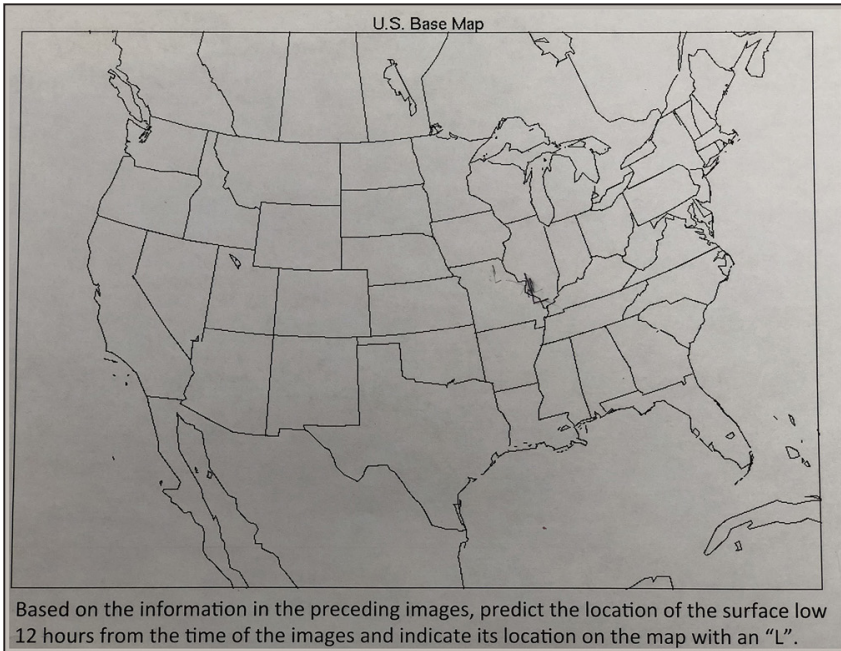

Expert example, base map (click image to enlarge).

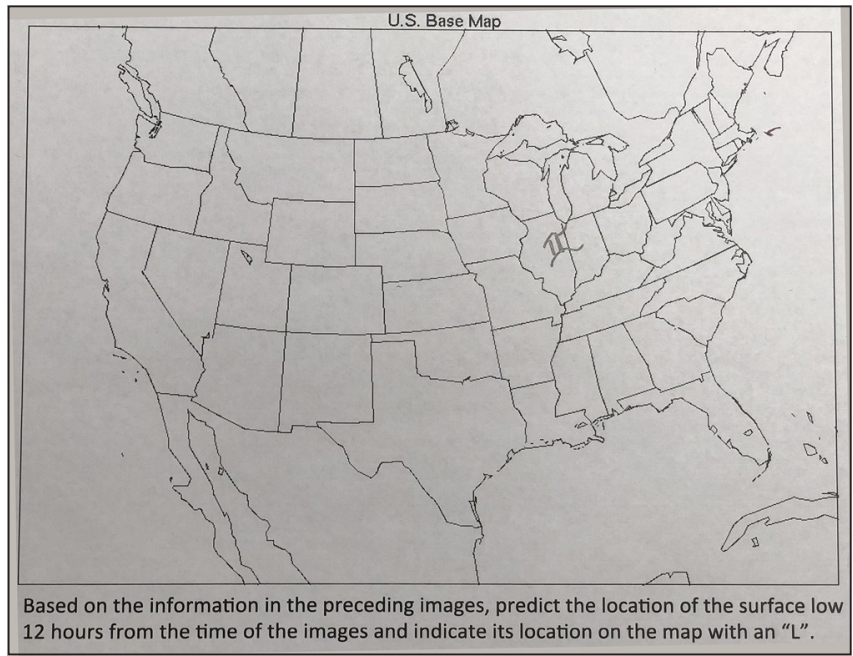




\section{APPENDIX D}

\section{Histograms and Normal Quantile-Quantile Plots for All Variables}
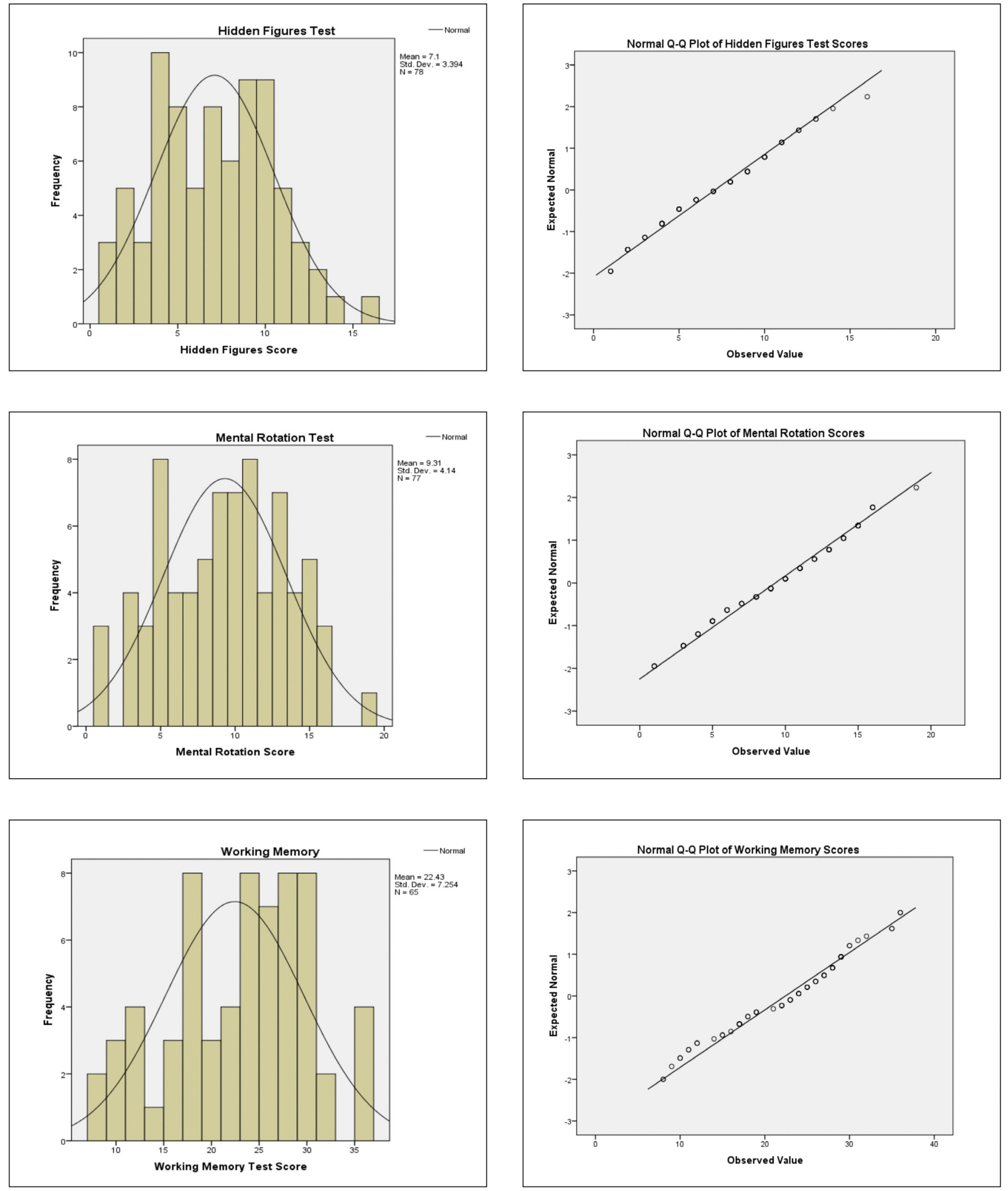
APPENDIX D (continued)
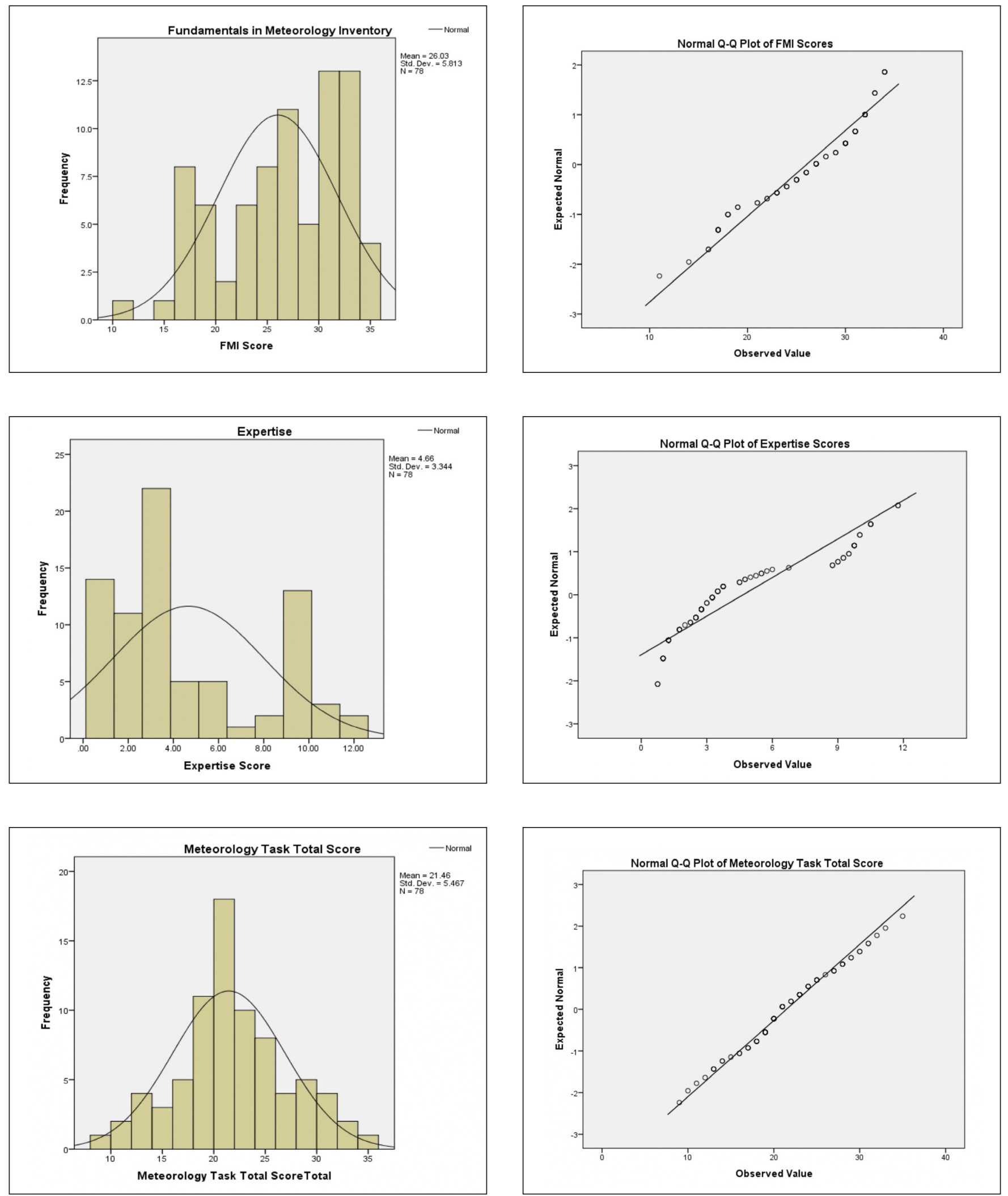
APPENDIX E

Plots of Residuals and Bivariate Relationships
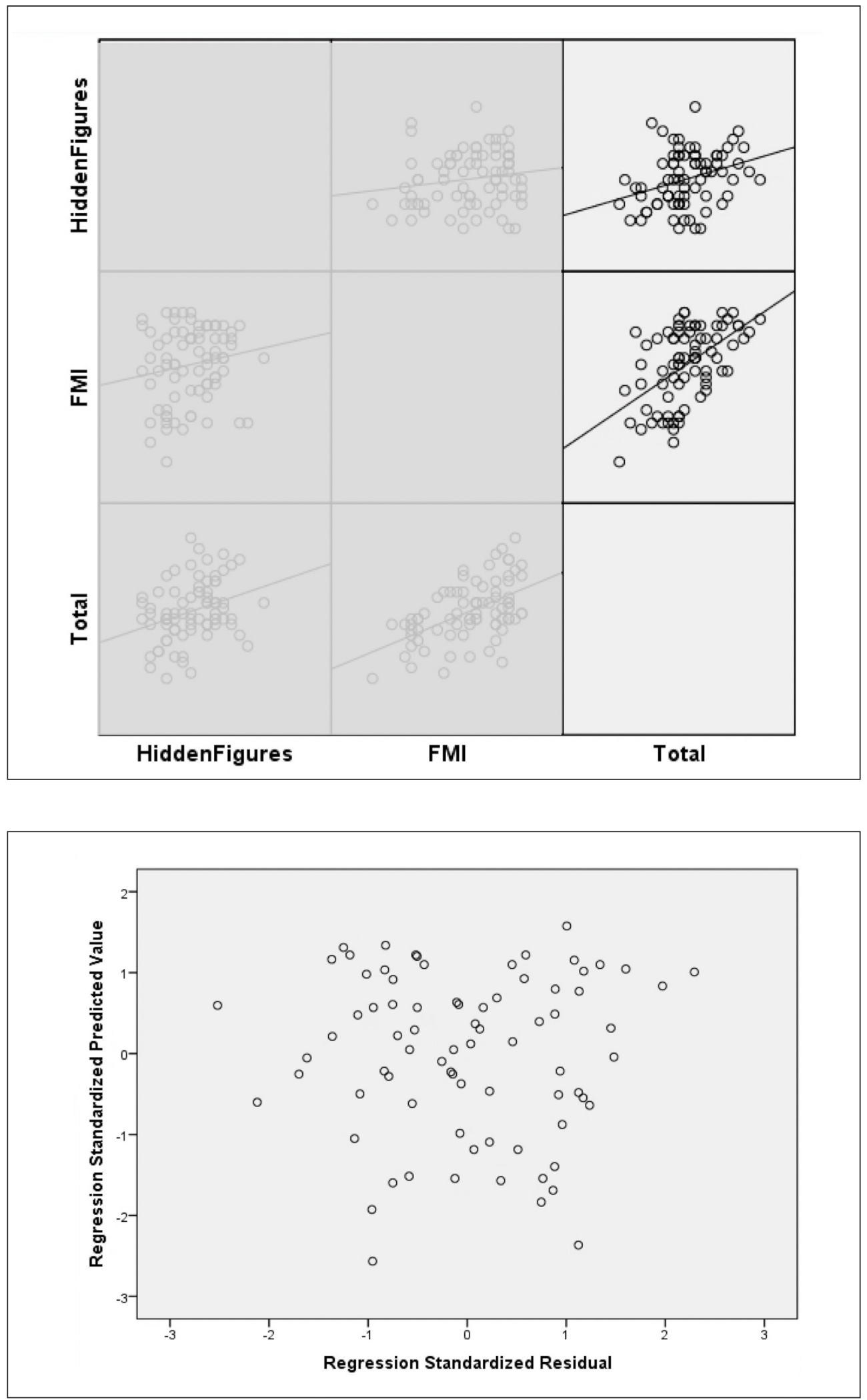


\section{REFERENCES}

Ackerman, P. L., R. Kanfer, and M. Goff, 1995: Cognitive and noncognitive determinants and consequences of complex skill acquisition. J. Exp. Psycho. Appl., 1, 270304, Crossref.

Atit, K., T. F. Shipley, and B. Tikoff, 2013. Twisting space: Are rigid and non-rigid mental transformations separate spatial skills? Cogn. Process., 14, 163-173, Crossref. , S. M. Weisberg, N. S. Newcombe, and T. F. Shipley, 2016: Learning to interpret topographic maps: Understanding layered spatial information. Cogn. Res. Prin. Implicat., 1 (2), 1-18, Crossref.

Baker, K. M., H. L. Petcovic, M. Wisniewska, and J. C. Libarkin, 2012: Spatial signatures of mapping expertise among field geologists. Cartogr. Geogr. Inf. Sci., 39, 119-132, Crossref.

Bédard, J., and M. T. Chi, 1992: Expertise. Curr. Dir. Psychol. Sci., 1, 135-139, Crossref.

Bolton, M. J., L. K. Ault, D. M. Greenberg, and S. BaronCohen, 2018: Exploring the human side of meteorology: A brief report on the psychology of meteorologists. $J$. Operational Meteor., 6 (3), 23-32, Crossref.

Bryant, B., M. Holiner, R. Kroot, K. A. Sherman-Morris, W. B. Smylie, L. Stryjewski, M. Thomas, and C. I. Williams, 2014: Usage of color scales on radar maps. J. Operational Meteor., 2 (14), 169-179, Crossref.

Charness, N., 1991: Expertise in chess: The balance between knowledge and search. Toward a General Theory of Expertise: Prospects and Limits, K. A. Ericsson and J. Smith, Eds., Cambridge University Press, 39-63.

Chase, W. G., and H. A. Simon, 1973: Perception in chess. Cogn. Psychol, 4, 55-81, Crossref.

Conway, A. R. A., M. J. Kane, M. F. Bunting, D. Z. Hambrick, O. Wilhelm, and R. W. Engle, 2005: Working memory span tasks: A methodological review and user's guide. Psychon. Bull. Rev., 12, 769-786, Crossref.

Danili, E., and N. Reid, 2004: Some strategies to improve performance in school chemistry, based on two cognitive factors. Res. Sci. Technol. Edu., 222, 203-226, Crossref.

Davenport, C. E., and A. J. French, 2018: The fundamentals in meteorology inventory: Results from the development of a new meteorology education tool. Preprints, 27th Symp. on Education, Austin, TX, Amer. Meteor. Soc., 5.5. [Available online at ams.confex.com/ams/98Annual/ webprogram/Paper328680.html.]

, C. S. Wohlwend, and T. L. Koehler, 2015: Motivation for and development of a standardized introductory meteorology assessment exam. Bull. Amer. Meteor. Soc., 96, 305-312, Crossref.

de Groot, A. D., 1965: Thought and choice in chess. Mouton, $463 \mathrm{pp}$.
Ekstrom, R. B., J. W. French, H. H. Harman, and D. Dermen, 1976: Kit of factor-referenced cognitive tests. Office of Naval Research Contract N00014-71-C-0117, Educational Testing Service, 314 pp. [Available online at www.ets.org/Media/Research/pdf/Kit of Factor-Referenced_Cognitive Tests.pdf.]

Field, A., 2013: Discovering Statistics Using IBM SPSS Statistics. Sage Publications, 916 pp.

Hambrick, D. Z., and R. W. Engle, 2002: Effects of domain knowledge, working memory capacity, and age on cognitive performance: An investigation of the knowledge-is-power hypothesis. Cogn. Psychol, 44, 339-387, Crossref.

, and F. L. Oswald, 2005: Does domain knowledge moderate involvement of working memory capacity in higher-level cognition? A test of three models. $J$. Mem. Lang., 52, 377-397, Crossref.

, and Coauthors, 2012: A test of the circumventionof-limits hypothesis in scientific problem solving: The case of geological bedrock mapping. J. Exp. Psycho. Gen. 141, 397-403, Crossref.

Hegarty, M., M. S. Canham, and S. I. Fabrikant, 2010: Thinking about the weather: How display salience and knowledge affect performance in a graphic inference task. J. Exp. Psycho. Learn., 36, 37-53, Crossref.

Hoffman, R. R., 1991: Human factors psychology in the support of forecasting: The design of advanced meteorological workstations. Wea. Forecasting, 6, 98110, Crossref.

Jaeger, A. J., T. F. Shipley, and S. J. Reynolds, 2017: The roles of working memory and cognitive load in geoscience learning. J. Geosci. Edu., 65, 506-518, Crossref.

Joslyn, S., and D. Jones, 2008: Strategies in naturalistic decision-making: A cognitive task analysis of naval weather forecasting. Naturalistic Decision Making and Macrocognition, J. M. Schraagen, L. Militello, T. Ormerod, and R. Lipshitz, Eds., Ashgate Publishing, 183-202.

Kali, Y., and N. Orion, 1996: Spatial abilities of high-school students in the perception of geologic structures. J. Res. Sci. Teach., 33, 369-391, Crossref.

Kastens, K. A., and T. Ishikawa, 2006: Spatial thinking in the geosciences and cognitive sciences: A cross-disciplinary look at the intersection of the two fields. Earth and Mind: How Geologists Think and Learn about the Earth, C. A. Manduca and D. W. Mogk, Eds., Geological Society of America, 51-74. [Available online at www. raubal.ethz.ch/Courses/geog596/Kastens\&Ishikawa SpatialThinking_06@2007-05-24T22\%3B23\%3B00. pdf.] 
Kremen, W. S., K. C. Jacobsen, H. Xian, S. A. Eisen, L. J. Eaves, M. T. Tsuang, and M. J. Lyons, 2007: Genetics of verbal working memory processes: a twin study of middle-aged men. Neuropsychology, 21, 569-580, Crossref.

Liben, L. S., and S. J. Titus, 2012: The importance of spatial thinking for geoscience education: Insights from the crossroads of geoscience and cognitive science. Earth and Mind II: A Synthesis of Research on Thinking and Learning in the Geosciences, K. A. Kastens and C. A. Manduca, Eds., GeoScienceWorld, 51-70, Crossref.

, K. A. Kastens, and A. E. Christensen, 2011: Spatial foundations of science education: The illustrative case of instruction on introductory geological concepts. $\operatorname{Cogn}$. Instr., 29, 45-87, Crossref.

MacPhee, D., and S. S. Canetto, 2015: Women in academic atmospheric sciences. Bull. Amer. Meteor. Soc., 96, 5967, Crossref.

Manduca, C. A., and K. A. Kastens, 2012: Mapping the domain of spatial thinking in the geosciences. Earth and Mind II: A Synthesis of Research on Thinking and Learning in the Geosciences, K. A. Kastens and C. A. Manduca, Eds., GeoScienceWorld, 45-49, Crossref.

McGee, M. G., 1979: Human spatial abilities: Psychometric studies and environmental, genetic, hormonal, and neurological influences. Psychol. Bull., 86, 889-918, Crossref.

McGrew, K. S., 2009: CHC theory and the human cognitive abilities project: Standing on the shoulders of the giants of psychometric intelligence research. Intelligence, 37, $1-10$, Crossref.

McNeal, P., T. Ellis, and H. Petcovic, 2018: Investigating the foundations of spatial thinking in meteorology. J. Geosci. Edu., 66, 246-257, Crossref.

Meinz, E. J., and D. Z. Hambrick, 2010: Deliberate practice is necessary but not sufficient to explain individual differences in piano sight-reading skill: The role of working memory capacity. Psychol. Sci., 21, 914-919, Crossref.

Newcombe, N. S., and M. Stieff, 2012: Six myths about spatial thinking. Int. J. Sci. Edu., 34, 955-971, Crossref. , and T. F. Shipley, 2015: Thinking about spatial thinking: New typology, new assessments. Studying Visual and Spatial Reasoning for Design Creativity, J. S. Gero, Ed., Springer, 179-192.

Ormand, C. J., C. Manduca, T. F. Shipley, B. Tikoff, C. L. Harwood, K. Atit, and A. P. Boone, 2014: Evaluating geoscience students' spatial thinking skills in a multiinstitutional classroom study. J. Geosci. Edu., 62, 146154, Crossref. , and Coauthors, 2017: The Spatial Thinking Workbook: A research-validated spatial skills curriculum for geology majors. J. Geosci. Edu., 65, 423-434, Crossref.
Petcovic, H. L., C. J. Ormand, and R. W. Krantz, 2016: Earth, mind, and paper: Field sketches as expert representations of the Hat Creek fault zone. 3-D Structural Interpretation: Earth, Mind, and Machine: AAPG Memoir 111, R. W. Krantz, C. J. Ormand, and B. Freeman, Eds., American Association of Petroleum Geologists, 173189.

Polderman, T. J. C., J. F. Stins, D. Posthuma, M. F. Gosso, F. C. Verhulst, and D. I. Boomsma, 2006: The phenotypic and genotypic relation between working memory speed and capacity. Intelligence, 34, 549-560, Crossref.

Roebber, P. J., and L. F. Bosart, 1996: The contributions of education and experience to forecast skill. Wea. Forecasting, 11, 21-40, Crossref.

Shipley, T. F., B. Tikoff, C. Ormand, and C. Manduca, 2013: Structural geology practice and learning, from the perspective of cognitive science. J. Struct. Geol., 54, 72-84, Crossref.

Titus, S., and E. Horsman, 2009: Characterizing and improving spatial visualization skills. J. Geo. Edu., 57, 242-254, Crossref.

Trafton, J. G., S. S. Kirschenbaum, T. L. Tsui, R. T. Miyamoto, J. A. Ballas, and P. D. Raymond, 2000: Turning pictures into numbers: Extracting and generating information from complex visualizations. Int. J. Hum. Comput. Stud., 53, 827-850, Crossref.

Uttal, D. H., N. G. Meadow, E. Tipton, L. L. Hand, A. R. Alden, C. Warren, and N. S. Newcombe, 2013: The malleability of spatial skills: A meta-analysis of training studies. Psychol. Bull., 139, 352, Crossref.

Vandenberg, S. G., and A. R. Kuse, 1978: Mental rotations, a group test of three-dimensional spatial visualization. Percept. Mot. Skills, 47, 599-604, Crossref.

Wai, J., D. Lubinski, and C. P. Benbow, 2009: Spatial ability for STEM domains: Aligning over 50 years of cumulative psychological knowledge solidifies its importance. $J$. Edu. Psychol., 101, 817-835, Crossref.

Wiley, J., 1998: Expertise as mental set: The effects of domain knowledge in creative problem solving. Mem. Cogn., 26, 716-730, Crossref.

, C. A. Sanchez, and A. J. Jaeger, 2014: The individual differences in working memory capacity principle in multimedia learning. The Cambridge Handbook of Multimedia Learning, R. E. Mayer, Ed., Cambridge University Press, 598-619.

Wilson, K. A., P. L. Heinselman, and Z. Kang, 2016: Exploring applications of eye tracking in operational meteorology research. Bull. Amer. Meteor. Soc., 97, 2019-2025, Crossref. 